\title{
ESTUDO COMPARATIVO DA MORFOGÊNESE FOLIAR EM SEIS CULTIVARES DE ALFACE (Lactuoa sativa L.)
}

\author{
MARCOS SALVADOR VILLALBA VAZQUEZ
}

Orientador: Prof. Dr. KEIGO MINAMI

\begin{abstract}
Dissertação apresentada à Escola Superior de Agricultura "Luiz de Queiroz", da Universidade de São Paulo, para obtenção do título de Mestre em Agronomia, Ârea de concentração: Fitotecnia.
\end{abstract}

$P|R A C| C A B A$

Estado de São Paulo - Brasil

Abril de 1986 
ii.

Ao meu pai

Marcos

(in memorium)

A minha mãe

Maria Pabla

Pelo carinho e orientação

Aos meus irmãos

Pelo apoio constante

MEU OFERECIMENTO

A minha esposa

carmen

e meu filho

Marcos

Pelo carinho, compreensão

e companheirismo de todas

as horas

MINHA DEDICAÇAO 


\section{AGRADECIMENTOS}

Os meus sinceros agradecimentos às seguintes pessoas e instituições:

- Ao Prof. Dr. Keigo Minami, pelo ensino, ami zade, dedicada orientação e grande estímulo à realização da presente pesquisa.

- Ao Ministério de Agricultura e Ganaderia de Paraguay, pelo apoio financeiro e em especial ao senhor Minis tro Eng: Agr: Hernando Bertoni; ao Eng? Agr? Luiz Alberto Alvares e ao Eng? Agr? Roberto Casaccia, pela oportunidade ofe recida para a realização deste ensino de Pós-Graduação.

- Ao Prof. Auxiliar de Ensino, Marcilio de Almeida, pelas sugestões valiosas no decorrer deste trabalho e pela amizade.

- A Escola Superior de Agricultura "Luiz Queiroz" da Universidade de São Paulo pela oportunidade para a realização do curso de Mestrado. 
.iv.

- Aos professores Docentes do Departamento de Agricultura e Horticultura da E.S.A. "Luiz de Queiroz", pelos ensinamentos ministrados e pela amizade.

- Aos colegas Pōs-Graduação e amigos da E.S.A. "Luiz de Queiroz" pela amizade sincera e momentos inesquecíveis.

- A todos que, direta ou indiretamente colaboraram durante o curso e na realização da dissertação e pela ami zade. 


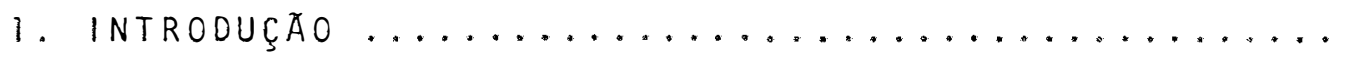

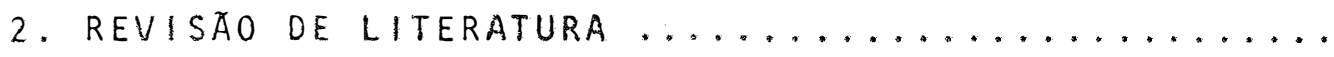

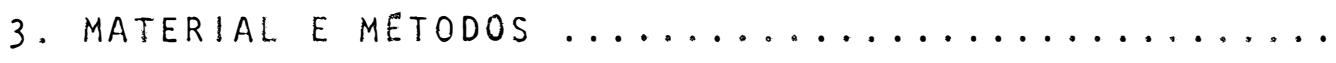

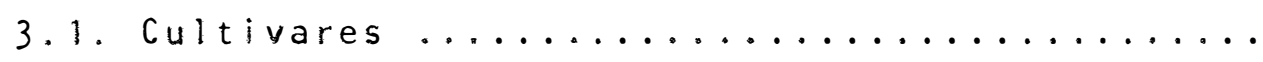

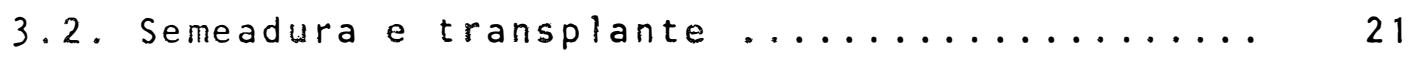

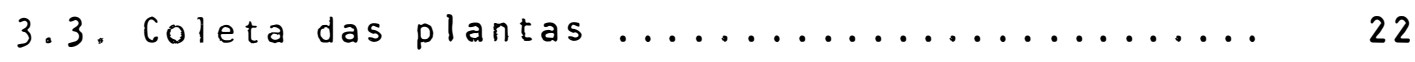

3.4. Preparo e conservação do material ......... 23

3.5. Contagem de nümero de folhas ........... 24

3.6. Desenho das plantas pelo método de camara cla

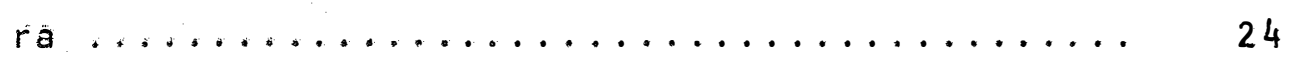

3.7. De ineamento experimental $\ldots \ldots \ldots \ldots \ldots \ldots$

4. RESULTADOS E DISCUSSAO ................. 27

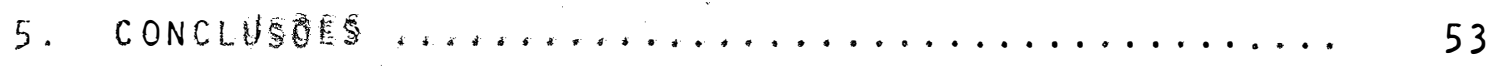

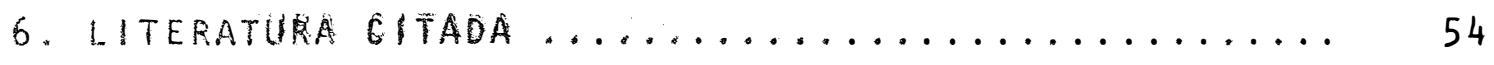




\title{
ESTUDO COMPARATIVO DA MORFOGENESE FOLIAR EM SEIS \\ CULTIVARES DE ALFACE (Lactuca sativa L.)
}

\author{
A] UnO: MARCOS SALVADOR VILLALBA VAZQUEZ \\ Orientador: Prof. Dr. Keigo Minami
}

\section{RESUMO}

A alface è uma hortaliça muito aprecidada e consumida quase exclusivamente na forma fesca, e as principais características de qualidade da folha, podem ser avaliadas através de um estudo morfogenético da mesma.

Para estudar a morfogênese foliar dentro do seu ciclo vegetativo utilizando-se os cultivares, Brasil 202 , Brasil 303, Boston Branca, Grand Rapids, Babä e Grandes Lagos, foi conduzido um experimento no Campo Experimental da Es cola Superior de Agricultura "Luiz de Queiroz", Piracicaba São Paulo, na ëpoca de maio-agosto de 1985.

Foi acompanhada semanalmente a evolução do desenvolvimento do nümero de folhas desde a emergência atē - final do ciclo vegetativo, ocorrido aos $85-95$ dias. 
A partir da segunda semana da emergência foram realizadas contagens semanais do nümero de folhas por planta, e desenhadas as figuras em câmara clara utilizando-se um Estereomicroscópio Wild $M-7$.

Foi verificado que as plantas de alface produzem folhas quase na forma linear com a idade. A emissão de folhas foi de maneira geral para todos os cultivares, e "foi relativamente lento no começo do ciclo, desde a emergência da plântula até 56 dias, com uma taxa de 2,3 folhas emitidas por semana durante as 8 semanas consecutivas nos diferentes cult vares estudados. Seguidamente com a anälise realizada aos 85 dias, verificou-se um grande aumento na taxa de emissão com uma média variāvel de 7 a 11 folhas por semana, durante 4 semanas consecutivas, atingindo uma média variável de 43,6 a 59,2 folhas por planta. Na ültima observaçãofeita aos 92 dias mostrou que os incrementos do nümero de folhas nos diferentes cultivares foram variāveis em relação a penūltima observaçäo.

Utilizando-se a câmara clara e atravēs do fixa dor Nawaschin para conservação dos materiais vegetais obteve- se bons pesultados no acompanhamento da emergência e crescimento das folhas, e portanto são recursos recomendāveis em es tudos semelhantes. 


\section{COMPARATIVE ESTUDY OF THE MORPHOGENESIS OF SIX CULTIVARS OF LETTUCE (Lactuca sativa $L$ ).}

Candidate: MARCOS SALVADOR VILLALBA VAZQUEZ Adviser: Prof. Dr. Keigo Minami

\section{SUMMARY}

Lettuce is a vegetable crop in which the very apreciated and principally consumed in the fresch form in wich the most important characteristics of the leaf quality, can be evaluated trough e morfphogenetic study of it.

To estudy morphogenesis of leaves during the vegetative cycle, was conducted one experiment at the "Escola Superior de Agricultura "Luiz de Queiroz", Piracicaba, SP, May to August of 1985. The cultivars were: Brasil 202, Brasil 203, White Boston, Grand Rapids, Babá, and Great Lakes.

Weekly observations of the growing development in relation with the number of leaves from emergence to the end of vegetative cycle, 85-90 days. 
. ix.

Since second week of emergence, were counted and designed the number of leaves per plant every week in clear chamber of a wild M-7 stereomicroscope.

It was checred that leaves were produced almost linearly with age of the lettuce plants. It was not differences between cultivars in relation to development of number of leaves; and was partially slow from the beggining to 56 days with a rate of 2.3 leaves per week, during 8 weeks.

At 85 days the rate was increased with a mean of 7 to 11 leaves per week, during four weeks, reaching 43.6 to 59.2 leaves per plant in average.

At the last observations made at 92 days, the number of leaves was variable in relation to the last but one.

By the use of the clear chamber methodology and Nawaschin fixer to storage the vegetative material was attained good results during emergy by and growth of leaves and therefore there are recommended in similars studies. 


\title{
1. INTRODUÇÃO
}

\begin{abstract}
A Alface (Lactuca sativa L.) pertence à família Compositae, mais recentemente classificada como Cichoriaceae. E uma planta herbācea que na fase vegetativa tem o caule curto, não ramificado ao qual prendem as folhas, estas säo grandes, 1 isas ou crespas fechando-se ou não na forma de uma cabeça; a coloração varia conforme o cultivar. Durante a etapa reprodutiva o caule sofre o alongamento e ramifica-se, e cada uma de suas ramificações forma uma inflorescência terminal, (FILGUEIRA, 1982). Trata-se de uma espécie anual, consi derada como planta de inverno para as condições do Brasil, com resistência a baixas temperaturas. Este è o fator ambien tal mais importante para a cultura da alface devido a que estä relaclonado com o espigamento, o qual provoca a formáça de um gosto amargo nas folhas. O periodo reprodutivo inicia- se com o pendoamento da planta, que é mais precoce a medida
\end{abstract}


que se eleva a atemperatura.

E cultivada por suas folhas que são consumidas quase exclusivamente na forma in natura, fresca em saladas, saduíches, e ocasionalmente é utilizada na forma cozida. A alface é muito procurada em todos os mercados do Brasil, sendo uma das hortaliças mais consumida e conhecida em todo o mundo. O consumidor brasileiro prefere as alfaces do tipo amanteigado de folhas lisas, verde claras que formam ca beça (CAMARGO, 1964). Hà diferenças nas preferências em cada pais, assim, nos EUA o cultivar mais consumido é o 'Great Lakes' que pertence ao tipo de cabeça com folhas crespas ou crocante. Morfogênese è o estudo da emergência e de forma de novos örgãos e seu arranjo no espaço. 0 desenvolvimento $\vec{e}$ portanto alcançado através de processos de crescimento, d ferenciação e morfogênese.

o esclarecimento da morfogênese da alface den tro do ciclo vegetativo, pode ser uma informação ütil para os trabalhos de nutrição e outros tratamentos a que é submetido a planta dentro de um processo produtivo.

o objetivo do presente trabalho foi estudar a emissão e crescimento de folhas em seis cultivares de alface durante a fase vegetativa,partindo do estägio de plàntula, até completar o ciclo vegetativo, para verificar o comportamento delas, observando em quantos dias atingem a formação 
. 3 .

total do nümero de folhas. Tambëm são comparadas entre si os diferentes cultivares em estudo no que se refere a nümero de folhas dentro do estägio de crescimento. 
.4.

2. REVISÃO DE Literatura

Os numerosos cultivares de alface existentes no mundo são classificados em cinco grupos (Rodemburg, citado por FILGUEIRA, 1982), e são os seguintes:

- Grupo Repolhuda Lisa: são cultivares com folhas lisas, aman teigados, formando cabeças bem compactas. Exemplos são: White Boston, Vivi, Brasil 303, Aurelia, Brasil 202, La Chaume, Cazard, Brasil 221, Mesa 659.

- Grupo Repolhuda Crespa: são cultivares com folhas crespas, crocantes, consistentes, formando cabeça compacta. Exemplos: Great Lakes, Imperial, New York.

- Grupo Solta Lisa: com folhas soltas e lisas, não formando cabeça. Exemplo: Gaba.

- Grupo Solta Erespa: Com folhas crespas e soltas consisten- 
tes, não formando cabeça. Exemplos: Grand Rapids, Black Seed Simpson.

- Grupo Romana ou Cos: São cultivares com folhas alongadas, formando uma cabeça alongada. Exemplos: Romana Balão, Gale ga.

No Brasil, numerosos experimentos foram feitos sobre os comportamentos dos cultivares de alface em diferentes ëpocas do ano e mesmo, melhoramentos que visaram obter novas variedades que suportam temperaturas mais elevadas e a lguns com resistência a virus.

CAMARGO (1964), comparando cultivares resisten tes às condições quente e umida de Minas Gerais, salientou o 'A-11-24' e'A-11-4', com mais elevadas produções e maior resistência ao espigamento.

Na região de Campinas, värios experimentos foram conduzidos, comparando principalmente produção e resistencia ao calor por BERNARDI e IGUE (1967-1969-1973) e por BERNARD et aliz (1973), ressaltaram como os mais produtivos os cultivares Great Lakes, Maravilha das Quatro Estaçös Shimabukuro, La Chaumé, New York, Repolhuda France sa, Cazard e Gigante. O'White Boston' caracterizou-se pela formação de cabeça e boa qualidade quando cultivada na época mais fresca do ano. 
Na região de Goiània, SONNEMBERG (1971), com um experimento realizado na época quente, afirmou como o cul tivar mais produtivo, a Grandes Lagos e logo seguiu o 'Romana', 'Babá', 'Cazard' e 'Boston Branca'. Num teste de prefe rência do consumidor foi melhor o Cazard e Boston Branca.

PEREIRA e BATISTA (1975), em experimentos rea lizados em três épocas diferentes, destacaram-se como: os mais produtivos 'Babá', 'La Chaume', 'Piracicaba', 'Great La kes' e 'Brasil 48'.

BERNARD l et alii (1975), cultivando na ëpoca de março e maio, concluiram como os mais produtivos o 'Great Lakes' 'e 'New York', logo seguiram em ordem decrescente 'Cla se's Aurelia', 'White Boston', 'Brasil 48', 'Gigante', 'La Chaume', 'Cazard', 'Babā' e 'Piracicaba'.

PEREIRA e BATISTA' (1976), cultivando na época de junho-agosto, concluiram como os mais produtivos o'Kagra ner Verão'; logo seguem 'La Chaume', 'Gloria Nantes', 'Brasil 1.8' e por ültimo.'Babà'.

YOKOYAMA et alii (1979) concluiram como os mais produtivos o. 'Mesa 659', 'Great Lakes' e 'A-11-4'; segue O 'Babấ', 'Bras 11 48' e 'Grand Rapids'.

PEREIRA et alii (1980) compararam o comportamento de novos cultivares com autros já conhecidos. Conclui ram como os mals produtivos o "Maravinha de Verão", 'Summer 
Queen'e'Brasil 48', quando cultivadas na época maio-junho; e na época de agosto-outubro destacaram-se o'Summer Queen', 'Kagraner', 'Kagraner Summer', 'Brasil 48', 'Brasil 202 ' e 'Maravilha de verão'.

VIGGIANO e MEDINA (1980) trabalharam com culti vares do grupo repolhuda lisa na época de junho-setembro. De tacaram-se o'Novir', 'Brasil 221 ', 'Vivi' e 'Augusta', com bom fecha mento de cabeças.

SENO et alii (1980) testaram oito cultivares na época de maio e setembro para estudar a interação cultivar $x$ época de plantio. 0 'Vivî e 'Great Lakes' mostraram suas produções maiores e bastante estäveis nas duas épocas. Quanto ao nümero de folhas por planta, o'Cazard', 'Romana'e 'Grand Rapids' produziram maior nümero de folhas na época de maio, mostrando-se mais sensivel à ëpoca de cultivo. Em relação ao pe so das folhas, apenas 'Vivi'não diferiu nas duas épocas, sendo que os demais apresentaram maior peso de matéria seca quando cultivados em maio.

RECHIN e LOIOLA (1982) estudaram o comportamen to de cultivares de alface, nos aspectos de produção e qualidade do produto em época em que ocorre fácil estímulo ao espi gamento precoce. Destacaram-se 'Brasil 212', 'Brasil 221 ' e!viví, pelas caracteristicas de folhas lisas, coloração verde- clara, ausêtncia de antocianina, formação de cabeças. 
'Grand Rapids', 'Great Lakes', 'Brasil 202', 'Black Seed Simp son', apresentaram espigamento precoce; de comportamento intermediärio 'Dark Green', 'A-11-4' e 'Brasil 221'; o. 'Viví, foi o de esolgamento mais tardio.

No estudo da fisiologia do desenvolvimento do ciclo da alface, pode-se dividir em uma fase vegetativa e outra reprodutiva, que são muito influenciados por värios fatóres climáticos (ZINK, 1959).

Durante o crescimento vegetativo se a alfá ce ë exposta a temperaturas elevadas, ela passa mais rapidamente à fase reprodutiva. Para evitar tal problema devem cul tivar-se em regióes microclimäticas favoráveis com elevada al titude, principalmente quando se quer produzir em ëpocas mais quentes do ano. A germinação jä começa ser afetada pelos fä tôres externos principalmente a luz e temperatura. As sementes que são frutosem aquênio podem apresentar dormência e está relacionada com a impermeabilidade do tegumento, a qual retarda trocas gasosas e influi na absorção de àgua o que dificulta ainda mais a germinação, também pode ser devido a acu mulaçé de produtos metabölicos. (Borthwick e Robbins, 1928; Thompson. 1938) citados por RYDER (1979). Além desses fatóres a dorméncia està intimamente relacionada com a temperatura e idade da semente. Se as sementes de alface são plantadas quando o solo estä entre 25 e $30^{\circ} \mathrm{C}$ pode dificultar a ger minação, rẹultando um stand fraco, embora a $20^{\circ} \mathrm{C}$ seja normal. 
(HARRINGTON e THOMPSON, 1952). Esses autores observaram que há diferença na germinação de acordo com a região climätica na qual a alface foi produzida. A dormência se relaciona ain da com os tipos varietais existindo mais ou menos suscetiveis.

A indução de germinação tem sido pesquisada por värios autores, com resultados positivos. KAHN (1960) determinou que a giberelina è muito eficiente para promover a germinação, principalmente quando esse tratamento é usado simultaneamente com radiações de luz vermelha. Bortwick et alit, citado por RYDER (1979), observaram que a luz vermelha 660 nm promove a germinação, enquanto que radiações infra vermelhas $735 \mathrm{~nm}$ a reduzem. Observaram tambëm que a ação do espectro luminoso é a mesma tanto para germinação como para fotoperíodo. A tiureia na concentração de $0,5 \%$ foi muito eficiente para promover a germinação de sementes, com dormência. Tambëm pode-se quebrar a dormência através de tratamen tos com frio $0^{\circ}-5^{\circ} \mathrm{C}$ durante 48 horas.

A alface $\vec{e}$ uma hortaliça de inverno, produzin do bem no Estado de São Paulo na época mais fresca do ano (BERNARDI e IGUE, 1967). Para um bom desenvolvimento a boa prodü căo, exige temperatura mëdia 15,5 a $18,3^{\circ} \mathrm{C}$ (KNOTT, 1956).

CASSERES (1966) aponta que para a alface a temperatura altä ë fator responsävel pelo desenvolvimento preco ce do tálo floral e consequente alteração da qualidade, de 
vido a uma rāpida acumulação de lätex amargo nas nervuras foliares. EDMOND et alii (1967) afirmaram também que o principal fator ambiental na cultura da alface é a temperatura. Para o desenvolvimento de cabeças firmes e sölidas são necessärias temperaturas uniformemente frescas de 7,2 a $10^{\circ} \mathrm{C}$, combinados com temperaturas do dia de 12,8 a $26,7^{\circ} \mathrm{C}$. As temperatu ras noturnas elevadas parecem ser o principal fator responsävel da falta de boa qualidade de alface.

A alface è uma planta anual produzindo na primeira fase do seu ciclo um conjunto de folhas chamado vulgarmente cabeça, e em seguida quando as condições são propicias há emissão da haste floral produzindo então flores e sementes (couto. 1960). Sob o ponto de vista comercial de produção para mercado, é importante haver condições climäticas que favoreçam o crescimento da parte vegetativa. Por outro, la do, para produção de sementes há necessidade de condições favoräveis para passar da primeira à segunda fase do ciclo.

E uma planta anual que exige temperaturas amenas durante todo o seu ciclo de crescimento vegetativo, especialmente durante o desenvolvimento da cabeça (FILGUEIRA, 1982). Baixas temperaturas noturnas são mais importantes em relação às diurnas. Temperaturas de 20 a $30^{\circ} \mathrm{C}$ acelera o ciclocultural e resultam em plantas menores, caindo a produti vidade. As mais exigentes são as do grupo repolhuda lisa em comparaçäo com as repolhudas crespas e soltas lisas. o foto- 
periodo tambēm influi no desenvolvimento, exigem dias curtos durante a fase vegetativa, embora fotoperiodos longos e altas temperaturas como nos dias de veräo, aceleram grandemente o pendoamento da planta, entretanto a influência da tempe ratura é mais decisiva. Arthur et alii, citado por couto (1960), mostraram que as plantas de alface floresciam mais rapidamente quando expostas a dias longos, e podiam ficar em estado vegetativo indeterminadamente se os dias fossem de 5 horas de duração.

RAPPAPORT E WITTWER (1952) trabalharam com plantas do cultivar Great Lakes a diversas temperaturas noturnas, e fazendo previamente vernalização de um grupo de se mentes. Observaram que temperaturas noturnas mais baixas permitiram a formação de maior nümero de folhas por planta e maior nümero de dias em vegetação. Os dois experimentos rea lizados mostraram a mesma tendência. A vernalização das sementes aceleraram um pouco o ciclo das plantas, fazendo-os en trar na fase reprodutiva mais depressa do que as provenientes de sementes não vernalizadas. Estudando os efeitos das temperaturas noturnas, comprimento do dia e vernalização de sementes, comprovaram que as temperaturas noturnas mais baixas retardam o florescimento das plantas ao passo que dias mais longos e vernalização das sementes aceleram o florescimento. Entretanto, sob o ponto de vista de produção de plan tas para mercado, devem-se ter dias mais curtos e noites mais 
frescas do que valores criticos dos cultivares. Existem variedades de maior resistência ao calor, isto é, cultivares que tem valor crítico relativamente elevado em relação à exi gência em temperatura.

Em alface, os florescimentos são influenciados tanto por temperatura como por fotoperíodo e pode ser altera do por vernalização da semente, e induzido com giberelina em plantas desenvolvidas a, partir de sementes não vernalizadas; o florescimento pode ser acelerado quando a semente está ver nalizada (BUKOVAC e WITTWER, 1958). Num trabalho destes autores, a giberalina promoveu a floração em alface de cabeça, desenvolvidas tanto sob fotoperíodos curtos de $9 \mathrm{~h}$, como com pridos de $18 \mathrm{~h}$, e temperaturas baixas 10 a $13^{\circ} \mathrm{C}$ ou altas 18 a $21^{\circ} \mathrm{C}$. 0 efeito da giberelina foi aditiva para o caso de dias compridos, altas temperaturas e sementes vernalizadas. As plantas tratadas com giberelina não formaram cabeças e produziram um pendão comprido antes do aparecimento dos primórdios florais. Recomenda-se o uso deste produto para indu zir a floração precoce.

Bensink, citado por RYDER (1979), estudou a in fluência da temperatura, comprimento do dia, intensidade de luz e outros fatores no processo de formação de cabeça de a l face. Observou primeiramente o que estä relacionado com o tamantio de cabeca, e em segundo os efeitos que variam o tama nho e aúmero total de folhas. Verificou que a planta pro- 
duz folhas essencialmente em forma linear com a idade. 0 ín dice de produção de nümero de folhas aumenta com o aumento da intensidade de luz e a temperatura constante; e ou com in cremento da temperatura a intensidade constante. A largura e comprimento da folha respondem diferentemente às variações das condições ambientais. A largura da folha responde posit ivamente ao aumento do comprimento do dia e intensidade de 1uz. O comprimento da folha aumenta sob baixa intensidade de luz e dias curtos. Com alta intensidade de luz a extensão da nervura central das folhas é reduzida. A extensão da ne vura central é menos afetada pelo comprimento do dia. As pri meiras folhas são relativamente alongadas; subsequentes desenvolvimentos dependem das condições ambientais. Em baixas intensidades de luz ou dias longos as folhas se tornam alargadas; sob alta intensidade e dias curtos tem produzido foIhas relativamente alongadas. 0 tamanho da folha se reduz com altas intensidades luminosas e $\vec{e}$ favorecido com baixa in tensidade.

THOMPSON e KNOTT (1933) estudaram os efeitos da temperatura e fotoperíodo na produção de alface. Semearam o cultivar White Boston em casa-de-vegetação à temperatura mê dia de 15,5 a $21,1^{\circ} \mathrm{C}$. Logo um lote de plantas seguiu em ambiente normal, outro lote em condições de ambiente quente 21,1 a $26,7^{\circ} \mathrm{C}$, e um terceiro lote em condições mais frias de 4,4 a $10^{\circ} \mathrm{C}$. A metade dos lotes se desenvolvia sob cond 
ções normais de longitude do dia e a outra metade sob condições de dia comprido, $15 \mathrm{~h}$. Concluiram que sob condições de alta temperatura não houve formação de cabeça, independentemente do comprimento do dia. Em cada caso se desenvolvia uma roseta de folhas abertas. O pendão floral aparecia, primeiro em plantas que receberam altas temperaturas. 0 incremento do comprimento do dia pareceu não acelerar a inicia ção do pendão floral, embora sob condições de dias compridos, - caule se alonga mais rapidamente que sob condições normais. Quando cresceram sob condições normais de 15,5 a $21,1^{\circ} \mathrm{C}$, todas as plantas formaram cabeças independentemente do comprimento do dia. O primeiro pendäo floral apareceu um mes mais tarde nas plantas tratadas com 15,5 a $21,1^{\circ} \mathrm{C}$, que nas tratadas com 21,2 a $26,7^{\circ} \mathrm{C}$. O crescimento foi muito len to nas plantas mantidas em condiçóes de 10 a $15,5^{\circ} \mathrm{C}$, embora formassem também cabeças. E por üitimo aquelas mantidas sob temperaturas de 4,4 a $10^{\circ} \mathrm{C}$ não formaram cabeças e cresceram muito pouco.

$$
\text { SCAIFE (1973) tambèm investigou o efeito }
$$
temperatura sobre o crescimento relativo em seis cultivares de alface, relacionando com a temperatura. Encontrou que o crescimento em relação a mesma foi sigmoidal, onde o mäximo atingiu a $22^{\circ} \mathrm{C}$ aproximadamente e logo decaiu.

As condições ambientais em geral influiram so bre a formação da cabeça, a formação de folhas curvadas, res- 
ponsáveis pela floração e desintegração da cabeça. As flutuaçöes estacionais da temperatura são os principais fatores que afetam o desenvolvimento da cabeça. NOTHMANN (1976a,b; $1977 a$, b) estudou a morfologia da formação de cabeça em alface cos ou romana. Ele estabeleceu dois fatores que contri buem na formação da cabeça; acumulação sucessiva de folhas de similar comprimento no centro da cabeça, e progressivo cur vamento de folhas externas para o centro da cabeça. Segun do North, citado por NOTHMANN (1976), o curvamento relativamente tardio das folhas, quase totalmente desenvolvidas na alface tipo romana ē uma diferença marcada na formação de ca beça não compacta, comparando com as repolhudas, onde a cabe ça è um agregado de folhas que mantém sua forma curvada desde o inicio até o fim do crescimento da folha, resultando as sim em cabeças compactas e firmes.

NOTHMANN (1977) estudou os efeitos da tempera tura do solo sobre o desenvolvimento da cabeça do tipo romana, submetendo os tratamentos artificiais de $12,20,28$ e $36^{\circ} \mathrm{C}$, e uma testemunha de 18 a $21^{\circ} \mathrm{C}$ às $8 \mathrm{~h}$ e 25 a $28^{\circ} \mathrm{C}$ às $14 \mathrm{~h}$. A primeira diferença no desenvolvimento da cabeça foi notado depois de poucos dias. O efeito mais pronunciado, dü rante os primeiros 10 dias de tratamento, foi causada pela temperatura mais alta do solo, $36^{\circ} \mathrm{C}$, com um desenvolvimento pobre, de folhas torcidas e um murchamento temporario de algumas plantas. A formação de cabeça apresentou deformação 
das folhas curvadas, embora as plantas näo tratadas apresen tassem folhas normais. As plantas sob baixa temperatura cres ceram muito lentamente e as de temperatura elevada $28-36{ }^{\circ} \mathrm{C}$ cresceram rapidamente, embora apresentassem um crescimento anormal da cabeça. Em geral, altas temperaturas do solo ace leram a maturação de cabeça de alface expressada com folhas deformadas e um progressivo dessecamento das externas. 0 de senvolvimento de plantas jovens foi afetada negativamente a $28^{\circ} \mathrm{C}$ e mais ainda a $36^{\circ} \mathrm{C}$. Quase não houve formação de cabeça com menor nümero de folhas torcidas, acompanhada com uma severa danificação de folhas. As cabeças das plantas não tratadas seguiram um crescimento mais lento, mas formaram melhores cabeças com mais folhas dobradas, menor quantidade de folhas secas e deformadas no final do periodo. 0 ta manho da cabeça e peso foi severamente reduzido sob $36^{\circ} \mathrm{C}$; cima de $28^{\circ} \mathrm{C}$ aceleraram a elongação do caule.

A umidade relativa do ar tem muita influência no crescimento das plantas de alface. TIBBIS e BOTTENBERG (1976) estudaram o efeito da umidade relativa do ar na prodú çăo de alface do tipo cabeça amanteigada, submetendo a inflú ência de $85 \%$ e $50 \%$ de umidade atmosfërica a $20^{\circ} \mathrm{C}$, e 16 e 8 horas de luz diäria. Acompanharam o crescimento durante 4 semanas em um solo orgânico e solução nutritiva. Em ambos substratos, as taxas de crescimento foram significativamente ma is räpidas em plantas sob $85 \%$ que com $50 \%$. 0 mais alto ní 
vel de umidade aumentou o nümero de folhas a $15 \%$, o tamanho a $30 \%$, o peso de matéria seca $62 \%$, conteüdo de ägua na folha de 93 a 94\%, e maiores quantidades de cabeça comerciäveis num período de tempo menor. 0 stress de umidade induzido por deficiência de umidade atmosférica afetou significativamente o desenvolvimento normal da alface, embora as plantas sejam mantidas em niveis ötimos de umidade do solo.

NOTHMANN (1976) estudou a morfologia de forma ção de cabeça em alface do tipo romana, na ëpoca de primavera. Realizou medições semanals de värias partes da planta a partir dos 21 dias da emergência até o pendoamento floral, du rante 13 semanas. Verificou que o desenvolvimentofoi relativa mente lento, no começo do ciclo. A taxa de produção média de folhas foi 3 por semana durante 5 semanas consecutivas, 56 dias da germinação; mais tarde, com o inicio da formação de cabeça na sétima semana de observação, a taxa aumentou rapidamente com uma média de 10 folhas por semana e continuou com esta média até o início de floração. 0 comprimento da cabeça com aproximadamente $30 \mathrm{~cm}$ permanecia inalterada dos 76 a 96 dias. Mais tarde, quando as plantas tiveram 100 dias come çou o pendoamento, caracterizado por um alongamento do caule. Encontrou que o crescimento das folhas apresenta um comporta mento sigmoidal típico do processo de formação de cabeça na alface do tipo romana, as folhas permaneceram sem curvar-se até a formação de cabeça, embora a maioria das folhas expandi 
das havia estado erectas por algum tempo. Sö o progressivo curvament de muitas folhas durante a formação de cabeça dá a forma final fechada e compacta, a qual é uma diferença ad cional quando compara-se com a alface do tipo repolhuda onde umas poucas folhas curvadas indica logo o final da forma exterior da alface de cabeça. A cabeça compacta e firme é con sequência da acumulação de folhas dentro de folhas mais gran des que fecham entre si.

Segundo FELIPE (1979), uma planta reproduzida sexualmente, parte de um zigoto e operando conjuntamente com os processos de crescimento, diferenciação e morfogènese, che gará a ser adulta. Embora morfologicamente é possível separar o termo, crescimento de diferenciação, metabolicamente é dificil fazè-lo. Crescimento, é um aumento irreversível em tamanho, peso ou volume mediante conversão de sustâncias inorgânicas em proteínas e carbohidratos. A mitose das células e seu alongamento mediante vacuolização, constituem componentes fundamentais do crescimento.

- desenvolvimento é caracterizado pelo cresci mento e tambëm mudanças de forma do corpo de uma planta, as quais ocorrem por meio de padröes sucessivos de diferencia ção e morfogênese.

A diferenciação refere-se a todas as diferenças quali tativas que aparerem entre cëlulas, tecidos e ör- 
grăo durante o crescimento.

o ciclo de desenvolvimento de alface está cla ramente diferenciado em: vegetativo e reprodutivo. Aos ole ricultores apenas interessa o ciclo vegetativo da alface que se encerra quando a planta estiver completamente crescida. 


\title{
3. Material e Métodos
}

\begin{abstract}
o experimento foi conduzido no Campo Experimental do Setor de Horticultura da Escola Superior de. Agricultura "Luiz de Queiroz", em Piracicaba, Estado de São Paulo, localidade que tem as seguintes coordenadas geogräficas: latitude $22^{\circ} 42^{\prime} 30^{\prime \prime}$ sul e longitude $47^{\circ} 38^{\prime} 00^{\prime \prime}$ oeste, com alti tude de 576 metros. 0 solo pertence à unidade taxonomica La tosol Vermelho Escuro, com elevada porcentagem de matéria or gãnica. O clima é subtropical ümido com estiagem no inverno, temperaturas médias inferiores a $18^{\circ} \mathrm{C}$ no inverno. As temperaturas médias mensais durante o experimento foram de $19,0^{\circ} \mathrm{C}$ em mai•, $16,2^{\circ} \mathrm{C}$ em junho, $16,1^{\circ} \mathrm{C}$ em jultho e $19,2^{\circ} \mathrm{C}$ em agosto.
\end{abstract}

3.1. Cultivares

os cultivares que entraram em estudo foram os seguintes com suas respectivas caracteristicas: 
- Brasil 202 - cultivar desenvolvido pelo Instituto Agronômi co de Campinas. Resistente ao virus do mosaico da alface, comporta-se melhor em plantio de inverno. A planta é de folhas lisas, tenras, de coloração verde claro, formando cabeça compacta. Inicio de colheita 75 a 85 dias após a semeadura.

- Brasil 303 - cultivar também desenvolvido pelo Instituto Agronómico de Campinas. Resistente ao virus do mosaico da alface, com certa resistência ao florescimento precoce nos plantios de verão, embora se comporte melhor nos plantios de inverno. A planta $\vec{e}$ de folhas lisas amanteigada, de co loração verde-claro, formando cabeça compacta e grande. In I cio de colheita 75 a 85 dias após a semeadura.

- Boston Branca - cultivar nacional, oriundo da White Boston. A planta forma cabeça fechada, de folhas lisas, macias, de coloração verde claro. Não resiste ao calor e de espigamento precoce. Início de colheita 70 - 80 dias após a semeadura. Muito apreciada pelo consumidor brasileiro.

- Grand Rapids - cultivar mais resistente ao calor, podendo ser plantado o ano todo. Utilizado tanto para semeadura direta como em transplante. Planta de foihas grandes, de bordo ondulado e coloração verde-amarelada. Não forma ca- 
beça definida. Inicio da colheita 70 - 85 dias apōs a semeadura, na época mais fresca do ano.

- Baba - cultivar selecionado pela Escola Superior de Agricultura "Luiz de Queiroz" e mantido pelo Departamento de Hortaliças da AGROCERES. Bastante resistente ao calor, Po dendo ser plantado o ano todo. A planta é vigorosa, de fo lhas grandes, lisas e de coloração verde-claro. Não forma cabeça definida. Início da colheita $70-80$ dias apōs a semeadura.

- Grandes Lagos - Cultivar de mediana resistência ao calor, podendo ser plantado o ano todo. A planta forma cabeça com pacta e pesada, de folhas espessas, de bordo ondulado e co loração verde-escuro. As folhas internas ficam completamente estioladas. Início de colheita de 80 a 90 dias após a semeadura, sempre na ëpoca mais fresca do ano.

Trabalhando com estes seis cultivares, foi estudado os quatro grupos de alface mais importantes no Brasil, segundo FILGUEIRA (1982).

3.2. Semeadura e transplante

No dia 15.05 .85 , a semeadura foi feita em um 
canteiro previamente preparado, em sulcos lineares, separados a $15 \mathrm{~cm}$, utilizando-se dois gramas de sementes por metro qua drado e a uma profundidade de $0,5 \mathrm{~cm}$, em um total de quatro metros quadrados de superfície para cada cultivar. Uma vez semeadas era mantido o solo com umidade acima de $50 \%$ de àgua disponivel, mediante irrigacōes superficiais na forma de aspersão. Todos os cultivares germinaram uniformemente aos seis dias da semeadura.

No dia 27.06 .85 , aos 35 dias da emergência os seis cultivares foram transplantados para lugar definitivo, em canteiros previamente preparados, com espaçamento de $30 \times 25$ cm. As culturas foram conduzidas até o final do experimento, fazendo-se as capinas periödicas, irrigações necessärias e adubação de cobertura aos 25 dias apös o transplante, com 1 g de sulfato de amônia por planta.

\subsection{Coleta das plantas}

A amostragem das plantas foram tomadas aos 13 , $20,27,37,42,49,56,85$ e 92 dias respectivamente após a emergência da plântula, envolvendo assim desde o estádio de plántula até o completo crescimento vegetativo, momento em que passava para a fase reprodutiva que se caracteriza pela emissão do pendão floral. 


\subsection{Preparo e conservação do material}

As plantas de cada cultivar uma vez colhidas foram limpas, elimando-se as raizes e pontas de folhas. Para conservação do material gevetal foi utilizado o método de fixador Nawaschin segundo (SASS, 1958), que permitiu manter as amostras conservadas por muito tempo, para posteriormente serem anaiisadas.

o método de fixação do materiai que foi desen volvido por "Nawaschin", ë preparado da seguinte maneira: so lução $\underline{A}$ - água destilada $70 \mathrm{cc}$ + formol $30 \mathrm{cc}$; e solução $\underline{B}$ ägua destilada $90 \mathrm{cc}+$ äcido acētico $9 \mathrm{cc}+$ cromico $1 \mathrm{cc}$. As soluções A e B são misturadas em frascos de vidros onde jä encontra-se o material vegetal a ser fixado. Feito isto, o frasco é levado a uma bomba de vácuo por um período de cinco minutos aproximadamente. Após a retirada do material, ele é transferido para outro frasco que contem outra porção do mes mo fixador, sendo totalmente mergulhado. A troca de frascos se faz devido ao fato de que alguns componentes do fixador despreendem-se ao ser submetido à vàcuo. 0 frasco, com o material já fixado, permanece fechado, onde é conservado a të mais de um ano, dando suficiente tempo de ser trabalhado.

As amostras que foram tomadas atē 49 dias da germinação foram conservadas por este método; as de 56, 85 e 92 dias foram examinadas logo após a coleta dos materiais. 
Na Figura 1, observa-se as amostras do material fixado pelo mëtodo de Nawaschin, em frascos de vidro.

3.5. Contagem do nümero de folthas

De cada amostragem, tomadas as melhores plantas, foram selecionados e submetidas à contagem do nümero de folhas, desde as maiores atè o ültimo primördiofoliar, que nascem a partir da gema vegetativa crescimento. A con tagem das folhas maiores fol feita: a olho nü, e das folhas menores com ajuda de um estereomicroscōpio WILD M-7.

3.6. Desenho das plantas pelo método de camara clara

Das amostragens tomadas aos $13,20,27,37$, 42, 49 e 56 dias foram feitos cortes iongitudinais das plantas, dividindo-as ao meio com lâminas para barbear; seguidamente esquematizadas em um papel com a ajuda de uma camara clara de um estereomicroscōpio WILD M-7. O desenho foi ampliado oito vezes da amostra por meio do citado estereomi croscópio, que posteriormente sofreu uma redução de $25 \%$, ficando finalmente, com uma relação de $1 \mathrm{~mm}$ da amostra equivalente a $6 \mathrm{~mm}$ na Figura.

Simultaneamente foram feitas, dos mesmos cor- 
tes, cöpias fotogräficas para uma eventual comparação entre os dois mëtodos.

Na Figura 2, observa-se o estereomicroscōpio WILD M-7 utilizado para contagem de folhas e desenho em camara clara.

\subsection{Delineamento experimental}

o delineamento experimental utilizado para a anälise da variância foi completamente casualizado, com seis cultivares e cinco repetições. Para os dados de cada repetição foram tomas médias de duas amostras.

Para a comparação da média dos dados obtidos foi utilizado o teste de Tukey, ao nivel de 5\% de probabilida de. 


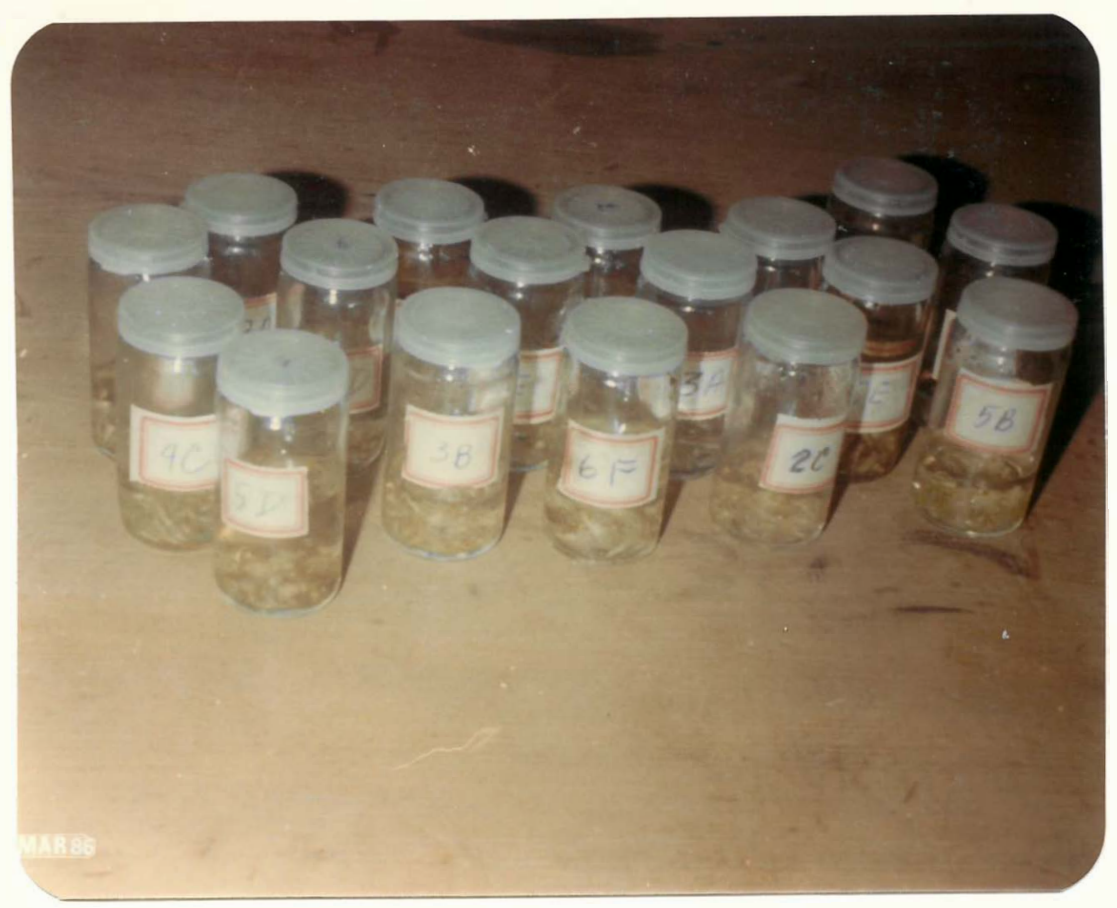

.27.

FIGURA 1. Conservação do material em frascos de vidro pelo método de fixador "Nawaschin".

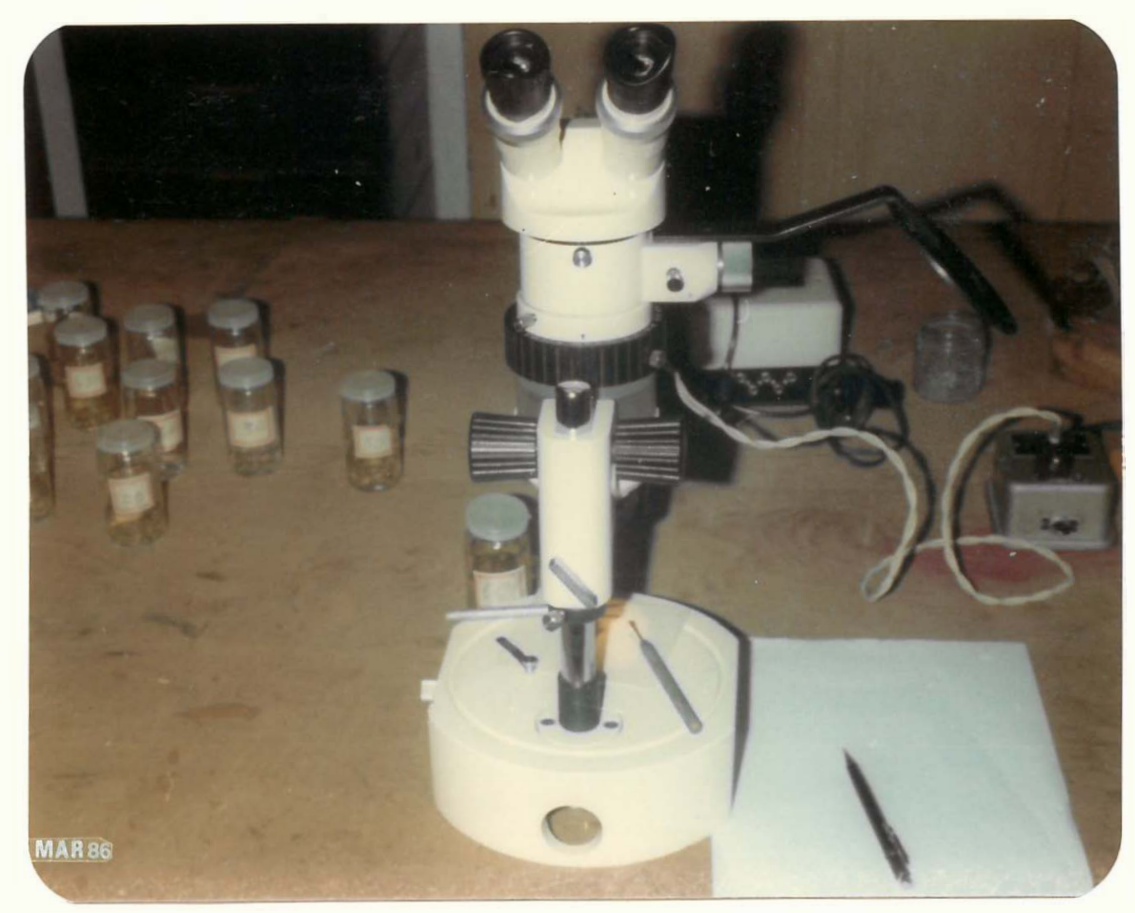

FIGURA 2. O Esterémicroscōpio WILD M-7 utilizado para esque matizar as figuras pelo método de câmara clara. 


\section{Resultados e Discussão}

Pelos resultados obtidos, observou-se que a emissão de folhas nos diferentes cultivares foi crescente, a medida em que os dias passaram apös a emergência da plântula, aumentando quase que linearmente em relação a idade da planta.

A esquematização das amostras tomadas, por meio da câmara clara atravēs de um estereomicroscōpio, foi um método muito eficaz e seguro, que permitiu examinar até os mais diminutos primördios foliares que se formavam mediante as Figuras 3 a 9.

A conservação do material vegetal pelo mëtodo de fixação "Nawashin" è muito ütil, por conservar por muito tempo, permitindo fazer os cortes e desenhos 
dos mesmos värios dias apös a colheita das amostras do campo experimental.

Nas Tabelas 1 a 9 e Figuras 3 a 11 são detalhados os resultados das contagens e desenhos reali zados nos diferentes estägios de crescimento vegetativo dos cultivares de alface.

Na primeira contagein de número de folhas, feito aos 13 dias da emergência da plàntula, pode-se observar na Tabela 1 e comparado na Figura 3. Neste estägio de crescimento vegetativo foi visto que os diferentes cultivares se encontraram com mëdias que variam de 4,36 a 5,60 folhas por planta.

TABElA 1. Mëdias do nümero de folhas por planta aos 13 dias da emergência da plântula.

\begin{tabular}{|c|c|c|c|c|c|c|c|}
\hline \multirow{2}{*}{ Cultivares } & \multicolumn{5}{|c|}{ Repet $\mathrm{i}$ ções } & \multirow{2}{*}{\multicolumn{2}{|c|}{ Médias }} \\
\hline & 1 & 2 & 3 & 4 & 5 & & \\
\hline 1. Br. 202 & 4,5 & 4,5 & 4,4 & 4,4 & 4,0 & 4,36 & c \\
\hline 2. Br. 303 & 5,5 & 4,0 & 4,5 & 5,0 & 4,0 & 4,60 & b c \\
\hline 3. B. Branca & 5,0 & 5,0 & 4,5 & 5,5 & 5,5 & 5,10 & $a b$ \\
\hline 4. G. Rapids & 5,0 & 5,5 & 6,0 & 6,0 & 5,5 & 5,60 & $a$ \\
\hline 5. Babà & 5,5 & 5,0 & 5,5 & 5,0 & 5,5 & 5,30 & a \\
\hline 6.G. Lagos & 6,0 & 5,0 & 5,0 & 5,0 & 5,5 & 5,30 & $a b$ \\
\hline $\begin{array}{ll}\operatorname{DMS}(5 \%) & =0,73 \\
\operatorname{CV} \% & =7,8\end{array}$ & & & & & & & \\
\hline $\begin{array}{l}\text { As médias segui } \\
\text { pelo teste de }\end{array}$ & da & ma & ra & & & & 5 \\
\hline
\end{tabular}



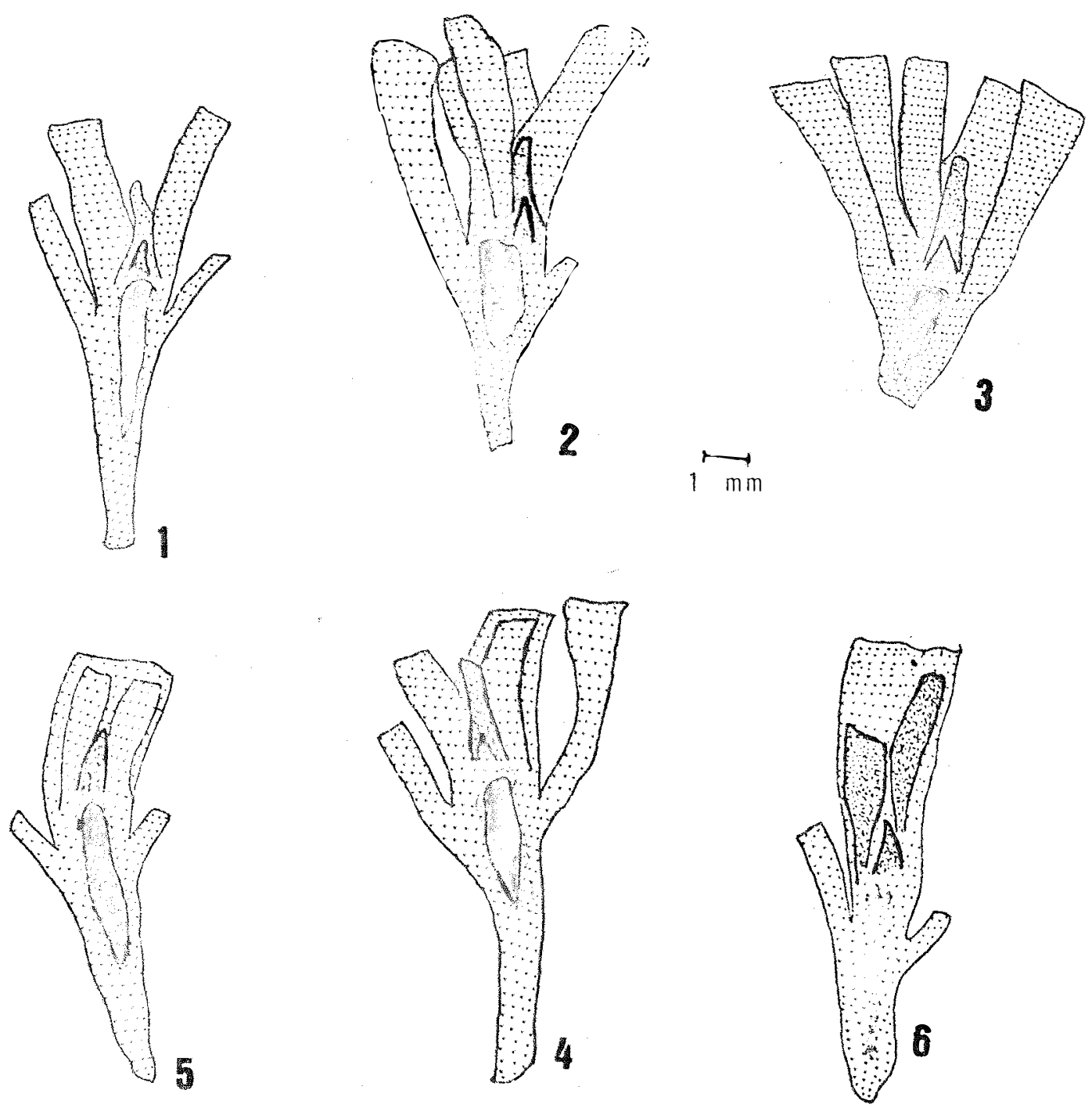

FIGURA 3. Cultivares de alface: 1. Br.202;2. Br.303; 3. B. Branca; 4. G. Rapids; 5. Baba; 6. G. Lagos. Número de follhas por planta aos 13 dias da emergência. Esquematizadas em câmara clara. 
Com a anālise da variància neste estāgio encontrou-se diferenças com alta significância entre os cultivares.

O 'Grand Rapids', 'Babä', 'Boston Branca' e 'Grandes Lagos' foram superiores e não diferiram entre si, e superiores ao 'Brasil $202^{\prime}$ que apresentou menor mëdia de nümero de folhas por planta neste estágio de desenvolvimento. 0 'Brasil $303^{\prime}$ não diferiu do 'Brasil 202', nen do 'Boston Branca' e 'Grandes Lagos'.

Na segunda contagem de nümero de follhas feito aos 20 dias da emergência da plântula pode-se observar na Tabela 2 e Figura 4 . Neste estägio de desenvolvimento, foi verificada que os diferentes cultivares encontram-se com as mëdias variäveis de 6,1 a 7,6 follhas por planta; resultando em sete dias, aumentos no nümero de folthas que variaram de 32 a $50 \%$

Com a anälise de variância neste estàgio encontrou-se tambēm diferença altamente significativa on de os cultivares ocuparam o mesmo ordem do estägio anterior. O 'Grandes Lagos', 'Boston Branca', 'Babà', Grand Rapids' foram superiores ao'Brasil 202' que outra vez se revelou com o menor nümero de folthas por planta. 
TABELA 2. Mëdias do nümero de follhas por planta aos 20 dias da emergência

\begin{tabular}{|c|c|c|c|c|c|c|c|}
\hline \multirow[b]{2}{*}{ Cultivares } & \multicolumn{5}{|c|}{ Repetições } & \multirow{2}{*}{\multicolumn{2}{|c|}{ Médias }} \\
\hline & 1 & 2 & 3 & 4 & 5 & & \\
\hline 1. Br. 202 & 6,0 & 6,5 & 6,0 & 6,0 & 6,0 & 6,10 & $b$ \\
\hline 2. Br. 303 & 7,5 & 6,5 & 6,5 & 7,5 & 6,5 & 6,90 & $a b$ \\
\hline 3. B. Branca & 7,5 & 7,0 & 8,0 & 7,0 & 7,0 & 7,30 & a \\
\hline 4. Rapids & 8,5 & 7,5 & 7,5 & 6,5 & 7,0 & 7,40 & $a$ \\
\hline 5. Babà & 7,0 & 7,5 & 7,0 & 7,0 & 7,5 & 7,20 & $a$ \\
\hline 6. G. Lagos & 8,0 & 7,5 & 7,5 & 7,5 & 7,5 & 7,60 & a \\
\hline
\end{tabular}

$\operatorname{DMS}(5 \%)=0,84$

$C V \%=6,40$

As médias seguidas das mesma letra não diferem entre si pelo teste de Tukey.

A contagem de nümero de folhas por planta do terceiro estägio, foị feita aos 27 dias da emergên cia da plàntula e pode ser vista na Tabela 3 e comparados na Figura 5; onde os diferentes cultivares aumentaramo nümero de folhas em relação à semana anterior. As mëdias na quarta semana variaram de 7,5 a 8,5 folhas por planta nos cultivares em estudo, resultando com aumentos de 9 a $18 \%$ em sete dias a mais de crescimento. 

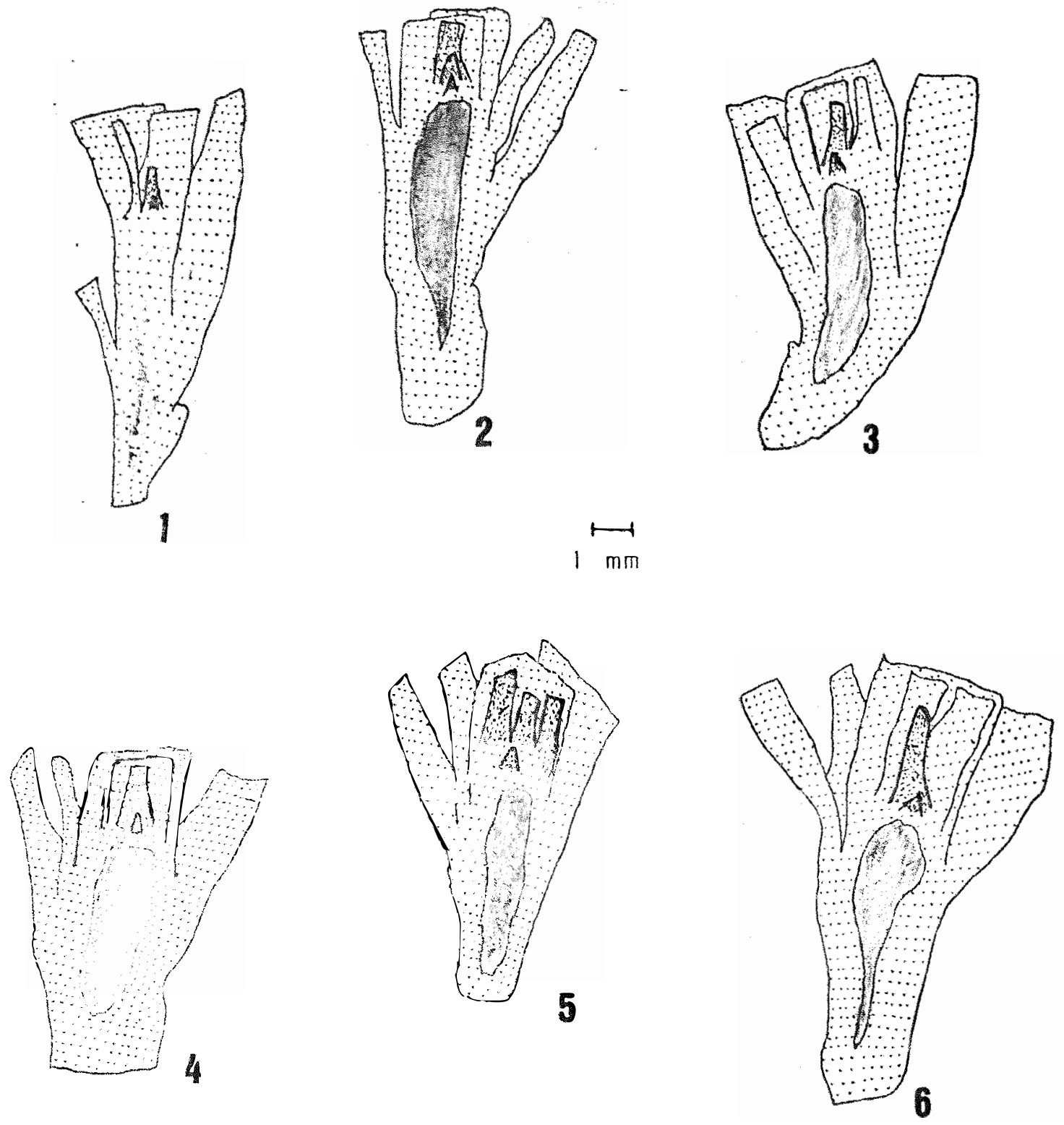

FIgura 4. Cultivares de alface: 1.Br.202;2.Br.303;3. B. Branca; 4. G. Rapids; 5. Baba; 6. G. Lagos. Nümero de folhas por planta aos 20 dias da emergência. Esquematizadas em càmara clara. 
TABELA 3. Mëdias do nümero de follhas por planta aos dias da emergência da plàntula.

\begin{tabular}{lccccccc}
\hline & \multicolumn{9}{c}{ Repetições } & \multirow{2}{*}{ Médias } \\
\cline { 2 - 5 } & 1 & 2 & 3 & 4 & 5 & \\
\hline 1. Br. 202 & 7,0 & 7,5 & 7,5 & 7,5 & 8,0 & 7,50 & b \\
2. Br. 303 & 8,0 & 8,0 & 7,5 & 7,5 & 7,5 & 7,70 & b \\
3. B. Branca & 8,5 & 7,5 & 7,5 & 8,0 & 8,5 & 8,00 ab \\
4. Rapids & 7,5 & 8,5 & 9,0 & 7,5 & 8,0 & 8,10 ab \\
5. Babán & 9,0 & 8,0 & 8,5 & 8,5 & 8,5 & 8,50 a \\
6. G. Lagos & 9,0 & 8,5 & 9,0 & 9,5 & 8,5 & 8,70 a
\end{tabular}

$\operatorname{DMS}(5 \%)=0,79$

CV\% $=5,30$

As médias seguidas da mesma letra não difercia entre si pelo teste de Tukey.

Na anälise de variància deste estägio encontrou-se também alta significància na diferença entre cultivares em quanto ao nümero de folhas por planta.

\section{O 'Grandes Lagos' e 'Babä' foram iguais}

e superiores a 'Brasil 202' e 'Brasil 303'. O. 'Grand Rapids' e 'Boston Branca' foram iguais e não diferiram dos demais cultivares.

A quarta observação do nümero de folhas emitidas por planta em cada cultivar, feita no inicio da sexa semana 

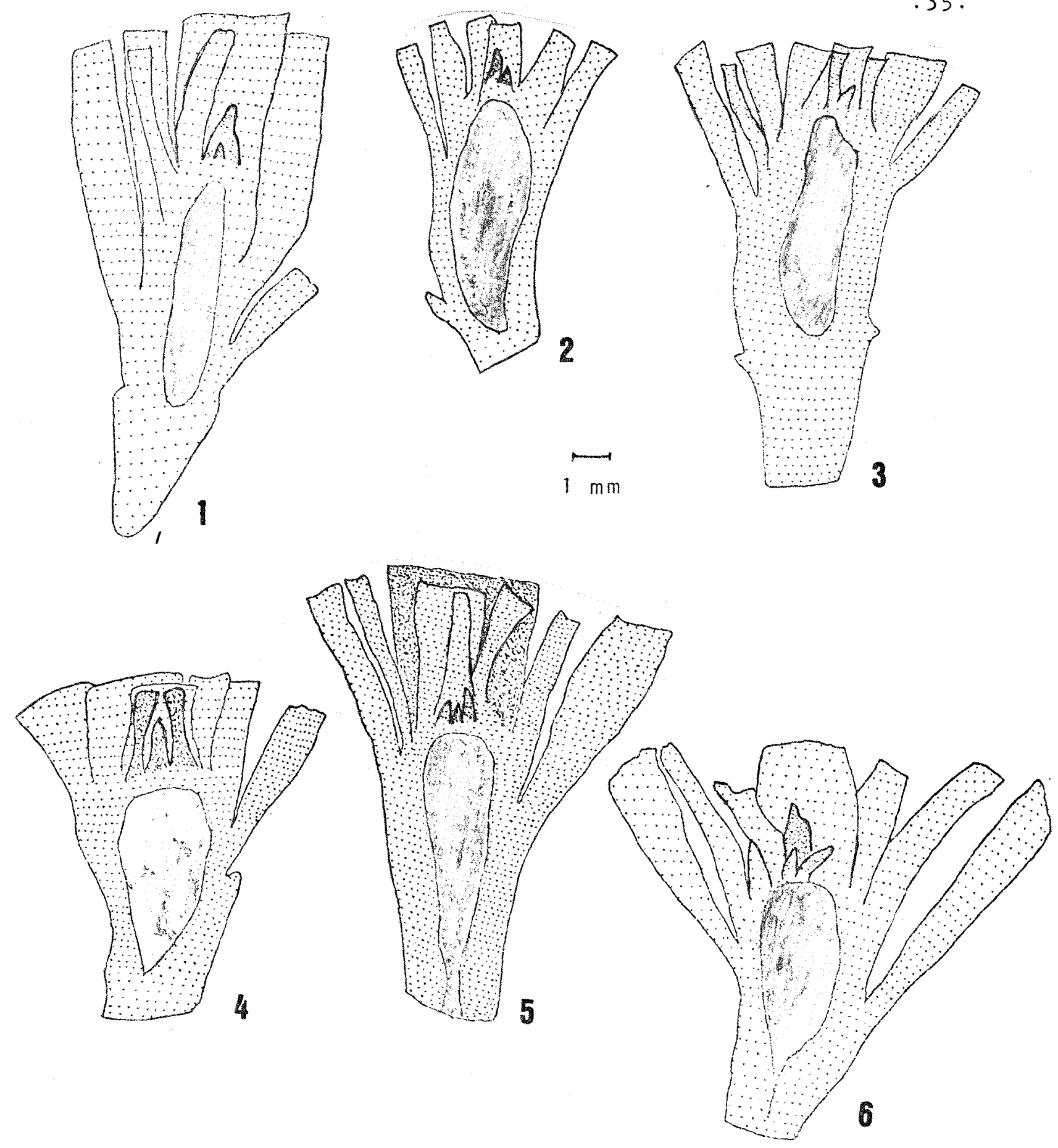

FIgURA 5. Cultixares de alface: 1. Br.202;2. Br.303;3. B. Branca; 4. G. Rapids; 5. Baba; 6. G. Lagos. Número de folhas por planta aos 27 dias da emergência. Esquematizadas em câmara clara. 
partir da emergência das plântulas encontram-se na Tabela 4 e desenhadas na Figura 6.

TABELA 4. Mëdias do nümero de folhas por planta aos 37 dias da emergência das plàntulas.

\begin{tabular}{lccccccc}
\hline \multirow{2}{*}{ Cultivares } & \multicolumn{9}{c}{ Repeticöes } & \multirow{2}{*}{ Mëdias } \\
\cline { 2 - 6 } & 1 & 2 & 3 & 4 & 5 & \\
\hline 1. Br. 202 & 11,0 & 11,0 & 10,5 & 11,0 & 10,5 & 10,80 & b \\
2. Br. 303 & 12,0 & 12,5 & 12,5 & 12,5 & 12,0 & 12,30 & a \\
3. B. Branca & 13,5 & 12,5 & 13,0 & 12,5 & 12,5 & 12,80 & a \\
4. Rapids & 13,5 & 12,5 & 12,5 & 12,0 & 13,5 & 12,80 a \\
5. Babá & 12,0 & 13,0 & 12,0 & 12,5 & 13,0 & 12,50 a \\
6. G. Lagos & 11,5 & 11,0 & 11,0 & 12,0 & 11,0 & 11,30 & b
\end{tabular}

$\begin{aligned} \operatorname{DMS}(5 \%) & =0,85 \\ & =3,80\end{aligned}$

CV\% $=3,80$

As inedias seguidas da mesma letra não diferem entre si pelo teste de Tukey.

As médias de número de folhas na sexta se mana fol de 10,8 a 12,8 por planta nos diferentes cultivares; con aumentos que variam de $29 \%$ a $60 \%$ em 10 dias apös.

A anälise de variância nesta idade da planta revelaram diferenças altamente significativa entre os diftentes cultivares;onde o 'Grand Rapids', 


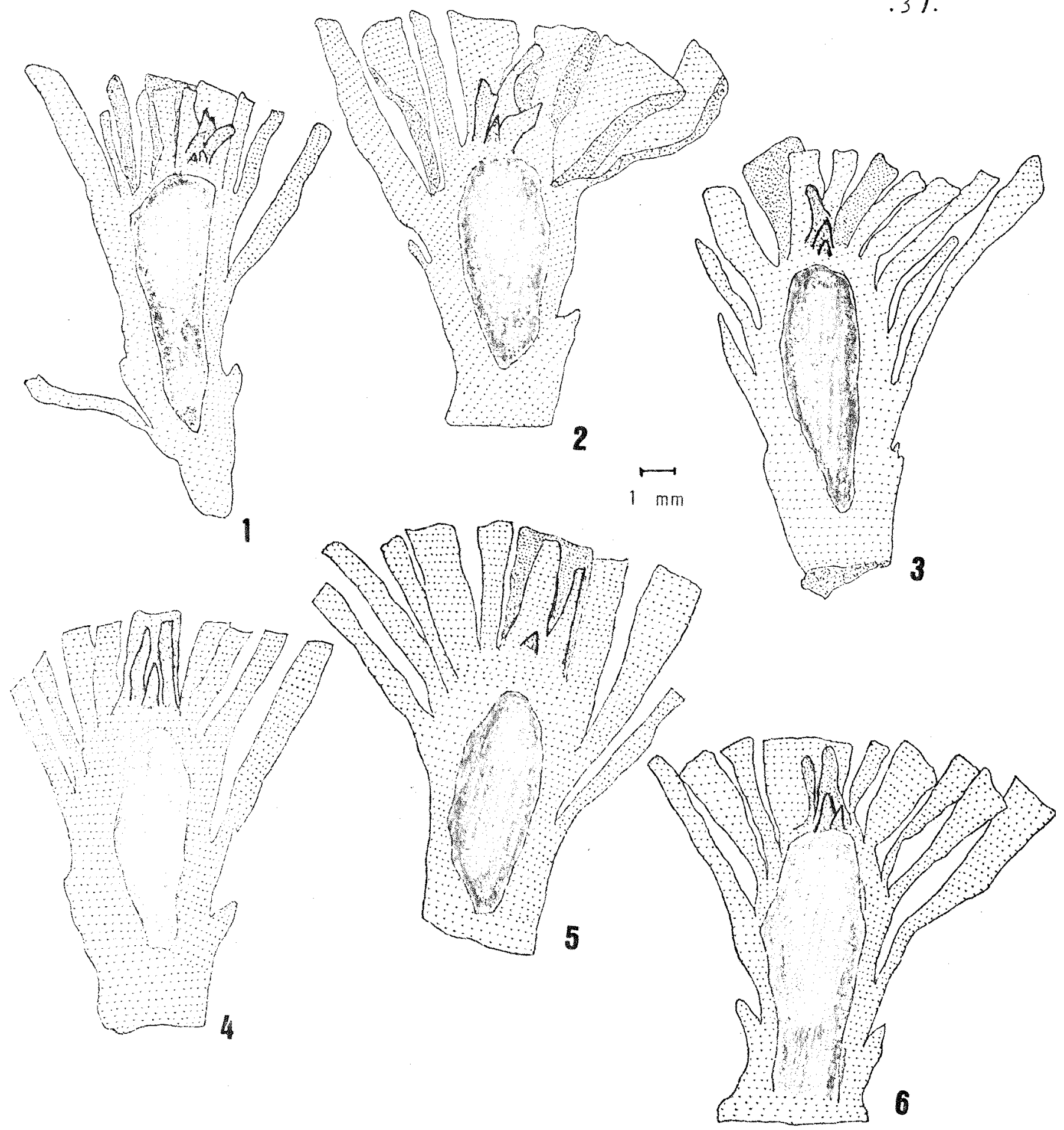

FIGURA 6. Cultivares de alface; 1. Br.202; 2. Br.303;3. B. Branca; 4. G. Rapids; 5. Babà; 6. G. Lagos. Nümero de folthas por planta aos 37 dias da emergência. Esquematizadas em câmara clara. 
'Boston Branca', 'Babä' e 'Brasil 303' não diferiram entre si, e superiores ao'Grandes Lagos' e 'Brasil 202', estas por sua ivez foram iguais entre si.

A contagem do nümero de folhas aos 42 dias da emergência, encontram-se na Tabela 5 e desenhados na figuras 7A e 7B. Nota-se que houve pequenos aumentos que variaram de $0 \%$ a $14 \%$ em relação a cinco dias anteriores. As médias variaram de 11,5 a 13,9 folhas por planta nos diferentes cultivares.

TABELA 5. Médias do nümero de folhas por planta 42 dias da emergência da plântula.

\begin{tabular}{|c|c|c|c|c|c|c|c|}
\hline \multirow{2}{*}{ Cultivares } & \multicolumn{5}{|c|}{ Repeticões } & \multirow{2}{*}{\multicolumn{2}{|c|}{ Mëdias }} \\
\hline & 1 & 2 & 3 & 4 & 5 & & \\
\hline 1. $\mathrm{Br} .202$ & 10,5 & 10,5 & 13,0 & 10,5 & 13,0 & 11,50 & $b$ \\
\hline 2. B. 303 & 12,0 & 14,5 & 12,0 & 13,5 & 13,0 & 13,00 & $a b$ \\
\hline 3. B. Branca & 14,0 & 13,5 & 13,5 & 14,0 & 13,5 & 13,70 & a \\
\hline 4. G. Rapids & 13,0 & 14,0 & 11,5 & 13,0 & 11,5 & 12,60 & $a b$ \\
\hline 5. Babá & 14,5 & 14,5 & 14,0 & 13,0 & 13,5 & 13,90 & $a$ \\
\hline 6. G. Lagos & 13,0 & 13,0 & 13,0 & 12,5 & 13,0 & 12,90 & $a b$ \\
\hline
\end{tabular}

As mēdias seguidas da mesma letra não diferem entre si pelo teste de Tukey.

Analisando os dados deste estägio encon- 

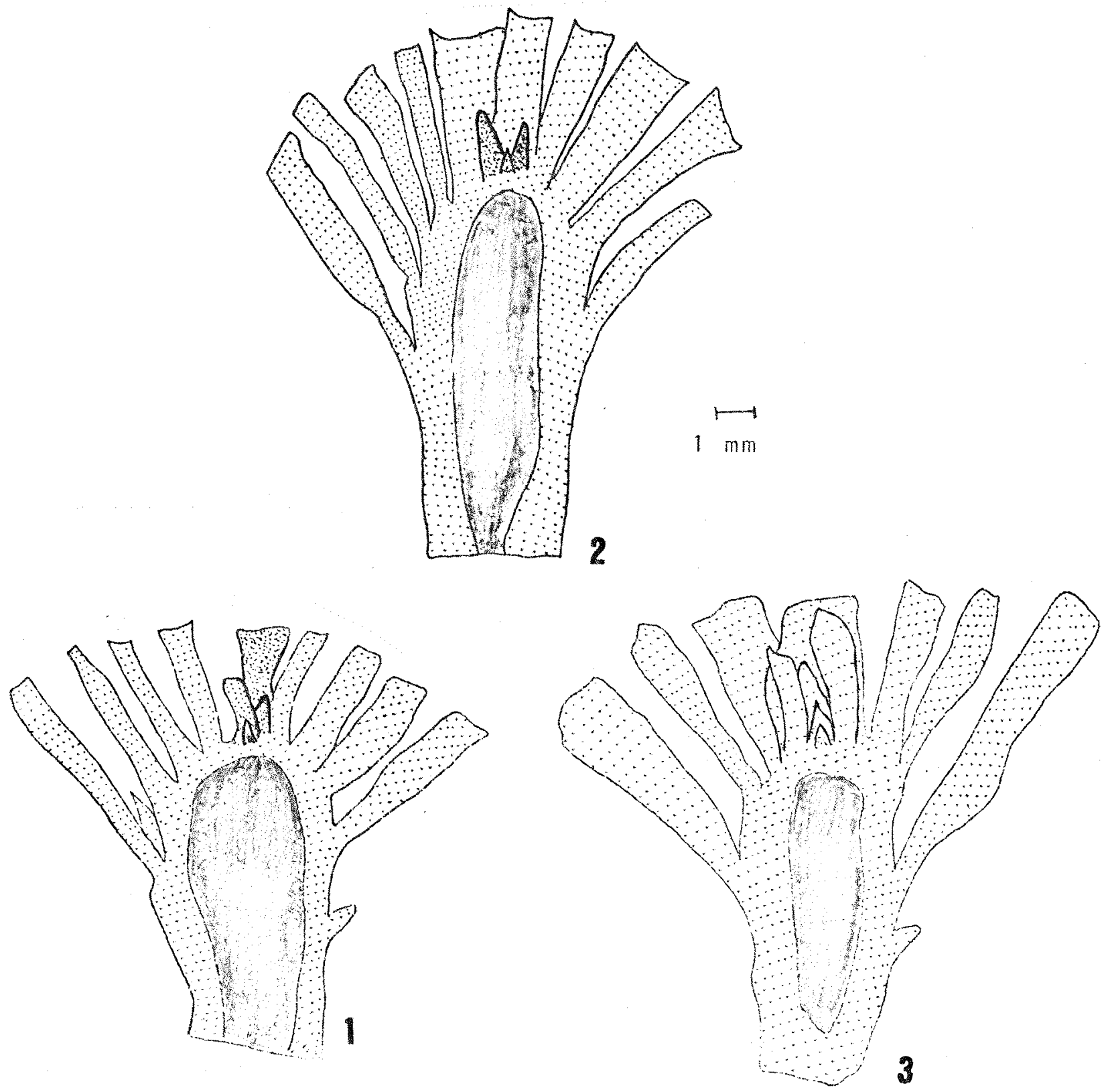

FIGURA 7.A. Cultivares de alface: 1. Brasil 202; 2. Brasil $303 ; 3$. Boston Branca. Numer de folhas por planta aos 42 dias da emergência. Esquematizadas em cámara clara. 


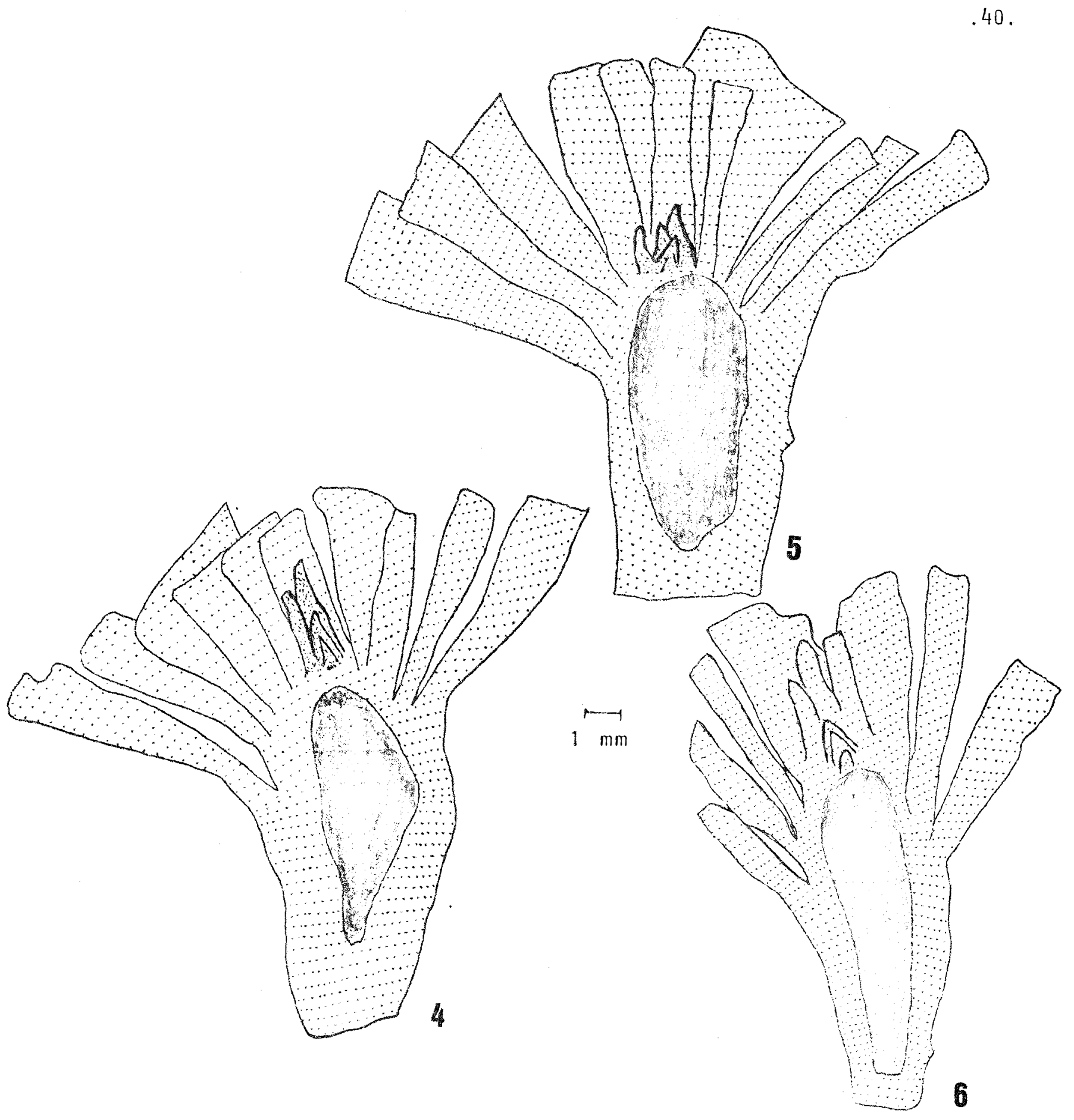

FlgurA 7.B. Cultivares de alface: 4. Grand Rapids; 5. Baba; 6. Grandes Lagos. Nümero de folhas por planta aos 42 dias da emergência. Esquematizadas em ca mara clara. 
.41.

traram-se diferenças altamente significativas entre si. os cultivares Babä, B. Branca foram superiores ao Brasil 202, embora não diferissem da 'Brasil $303^{\prime}$, 'Grandes Lagos' e 'Grand Rapids'; estas três ültimas por sua vez näo diferirami do 'Brasil 202'.

Os resultados da contagem de nümero de fo Ihas aos 43 dias da emergẽncia encontram-se na Tabela 6 e desenhados nas Figuras $8 A$ e $8 B$, onde pode observar-se que os mesmos seguem desenvolvendo-se mais folhas por planta. Em sete dias os aumentes de nümero defolhas variaram de $8,5 \%$ e $35 \%$ nots diferentes cultivares estudados.

TABELA 6. Médias do nümero de follhas por planta aos 49 dias da emergência da plàntula.

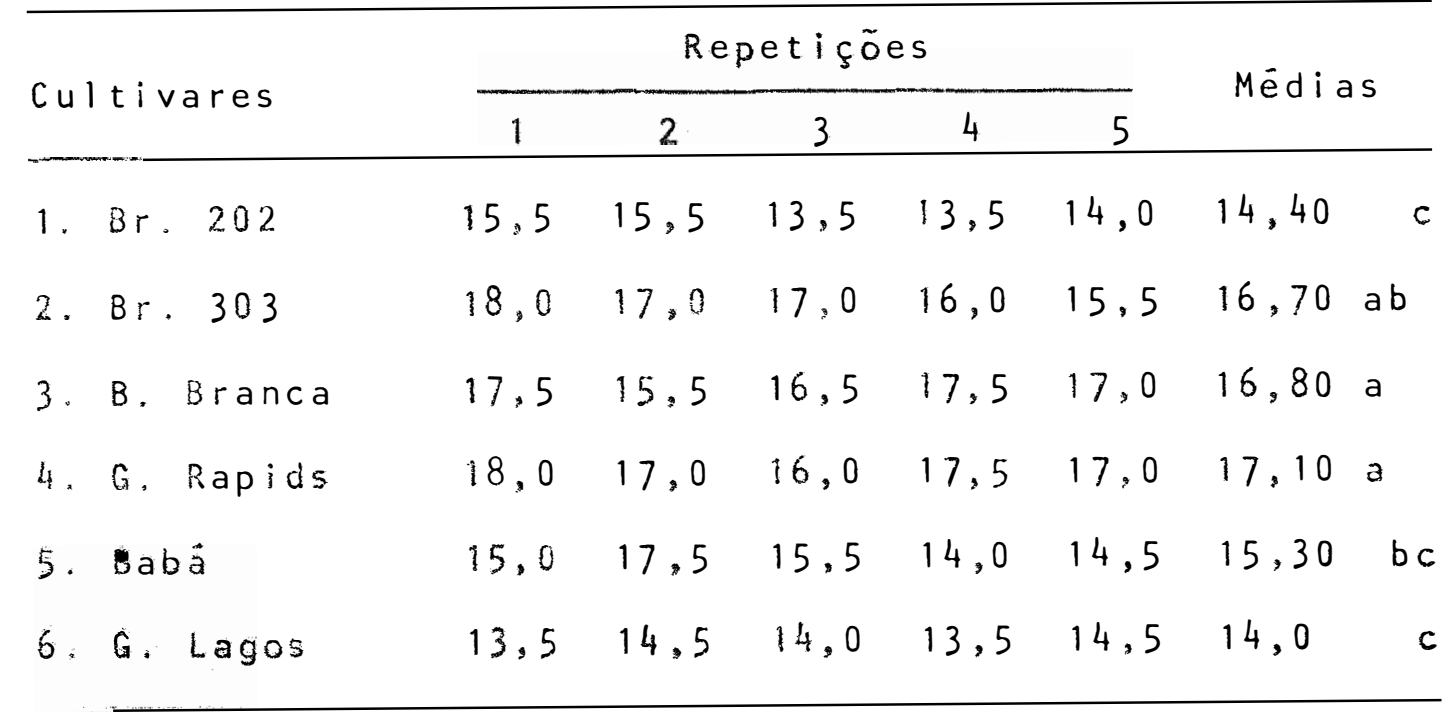

$\operatorname{DMS}(5 \%)=1,76$

$C V \%=6,0$

As mëdlas seguidas da mesma letra näo diferem entre si pelo teiste de Tukey. 


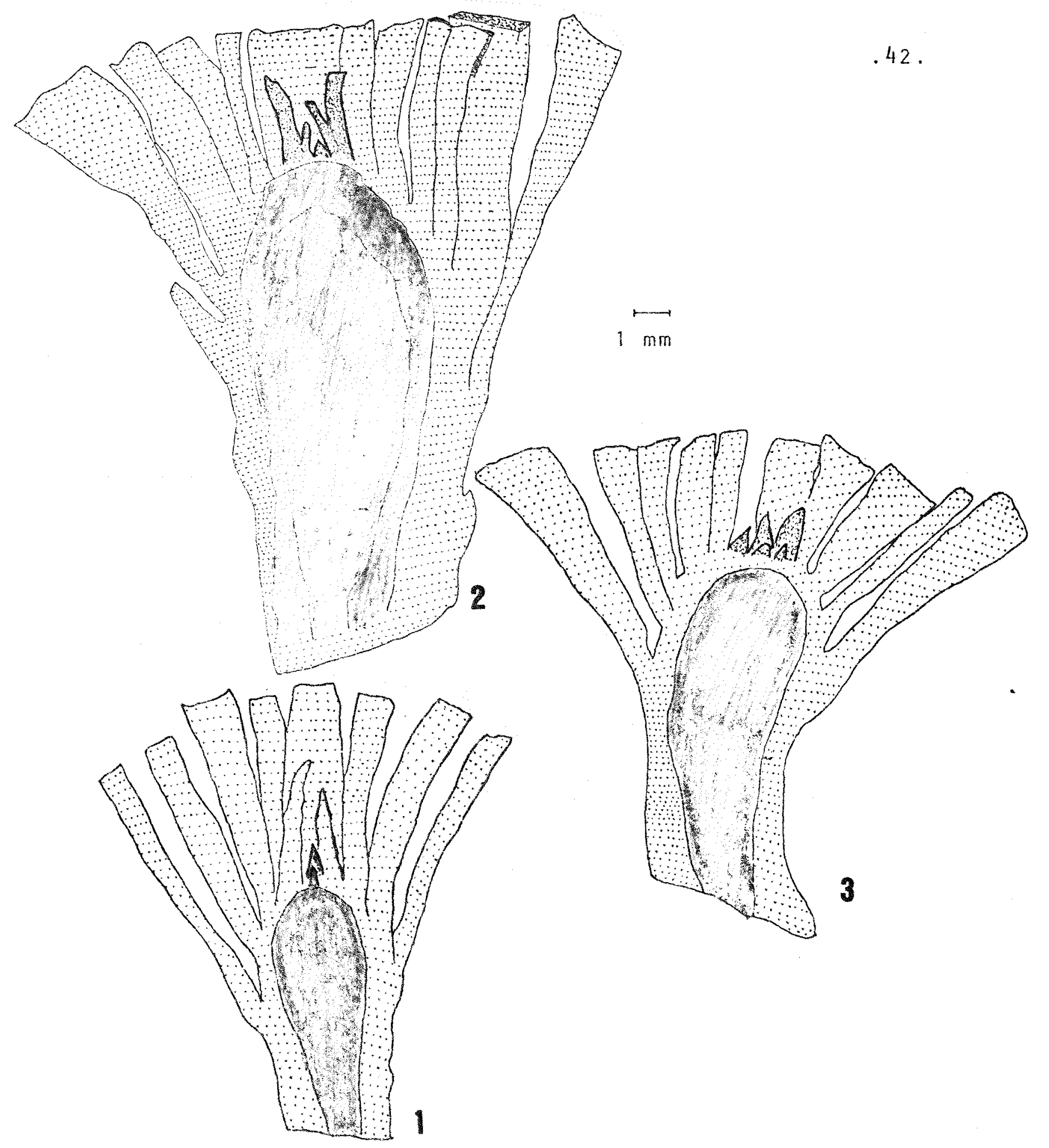

FIGURA 8.A. Cultivares de alface: 1. Brasil 202;2. Brasil $303 ; 3$. Boston Branca. Número de follhas por planta aos 49 dias da emergência. Esquematiza das em camara clara. 


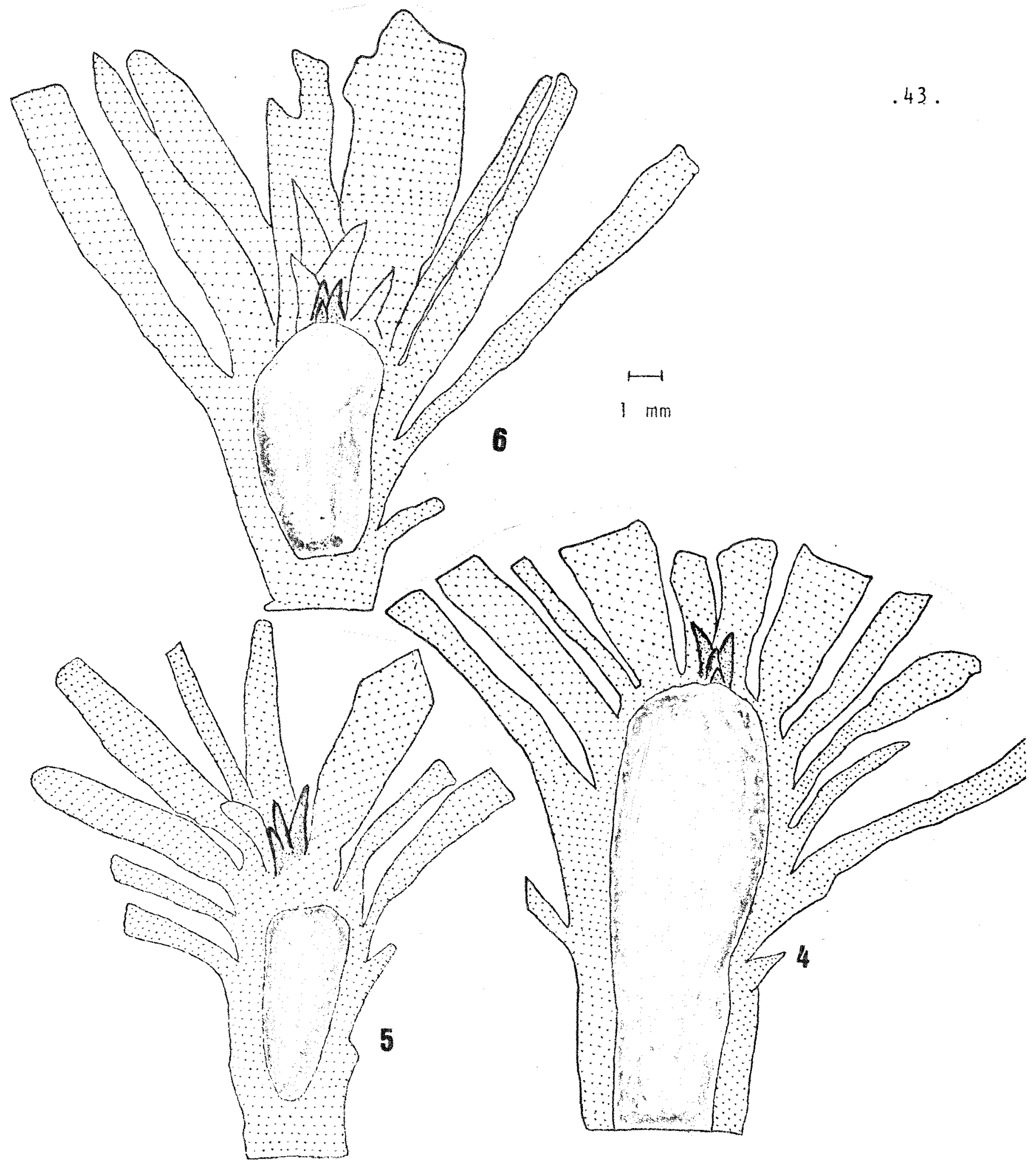

FIGURA 8.B. Cultivares de alface: 4. Grand Rapids; 5. Babä; 6. Boston Branca. Nümero de folhas aos 49 dias da emergência. Esquematizadas em camara clara. 
Pela anälise de variância, houve diferenças altamente significativas, onde o'Grand Rapids' e 'Boston Branca' foram superiores a 'Babä', 'Brasil 202', e 'Grandes Lagos'. O 'Brasil 303' não diferiu -do 'Grand Rapids', 'Boston Branca' e 'Babä'; porém superior também ao'Brasil 202' e 'Grandes Lagos'.

Na Tabela 7 e figuras $9 A$ e $9 B$ podem comparar-se os dados que se referem a contagem realizadas nos diferentes cultivares aos 56 dias da emergência.

Pode-se notar que houve pequenos aumentos que variaram de $0 \%$ a $11 \%$ am quanto a a umento do nümeros de folhas emitidas por plenta no decorrer de sete dias.

TABELA 7. Médias de nûmero de folhas por planta aos 56 dias da emergência das plântulas.

\begin{tabular}{|c|c|c|c|c|c|c|c|}
\hline \multirow{2}{*}{ Cultivares } & \multicolumn{5}{|c|}{ Repetiçoes } & \multirow{2}{*}{\multicolumn{2}{|c|}{ Médias }} \\
\hline & 1 & 2 & 3 & 4 & 5 & & \\
\hline 1. Br. 202 & 16,0 & 16,0 & 14,0 & 15,0 & 15,5 & 15,3 & $\mathrm{a}$ \\
\hline 2. Br. 303 & 16,5 & 14,0 & 17.5 & 17,5 & 17,5 & 16,6 & a \\
\hline 3. B. Branca & 19,0 & 17,5 & 16,0 & 17,0 & 15,0 & 16,9 & $a$ \\
\hline 4. G. Rapids & 18,0 & 18,0 & 19,0 & 16,5 & 17,5 & 17,8 & a \\
\hline 5. Babä & 15,5 & 16,0 & 16,5 & 14,5 & 18,5 & 16,2 & $a$ \\
\hline 6. G. Lagos. & 16,5 & 14,5 & 13,5 & 15,5 & 18,0 & 15,6 & $\mathrm{a}$ \\
\hline
\end{tabular}

$\operatorname{DMS}(5 \%)=2,56$

CV\% $=8,40$

As médias seguidas da mesma letra não diferem entre si pelo teste de Tukey. 


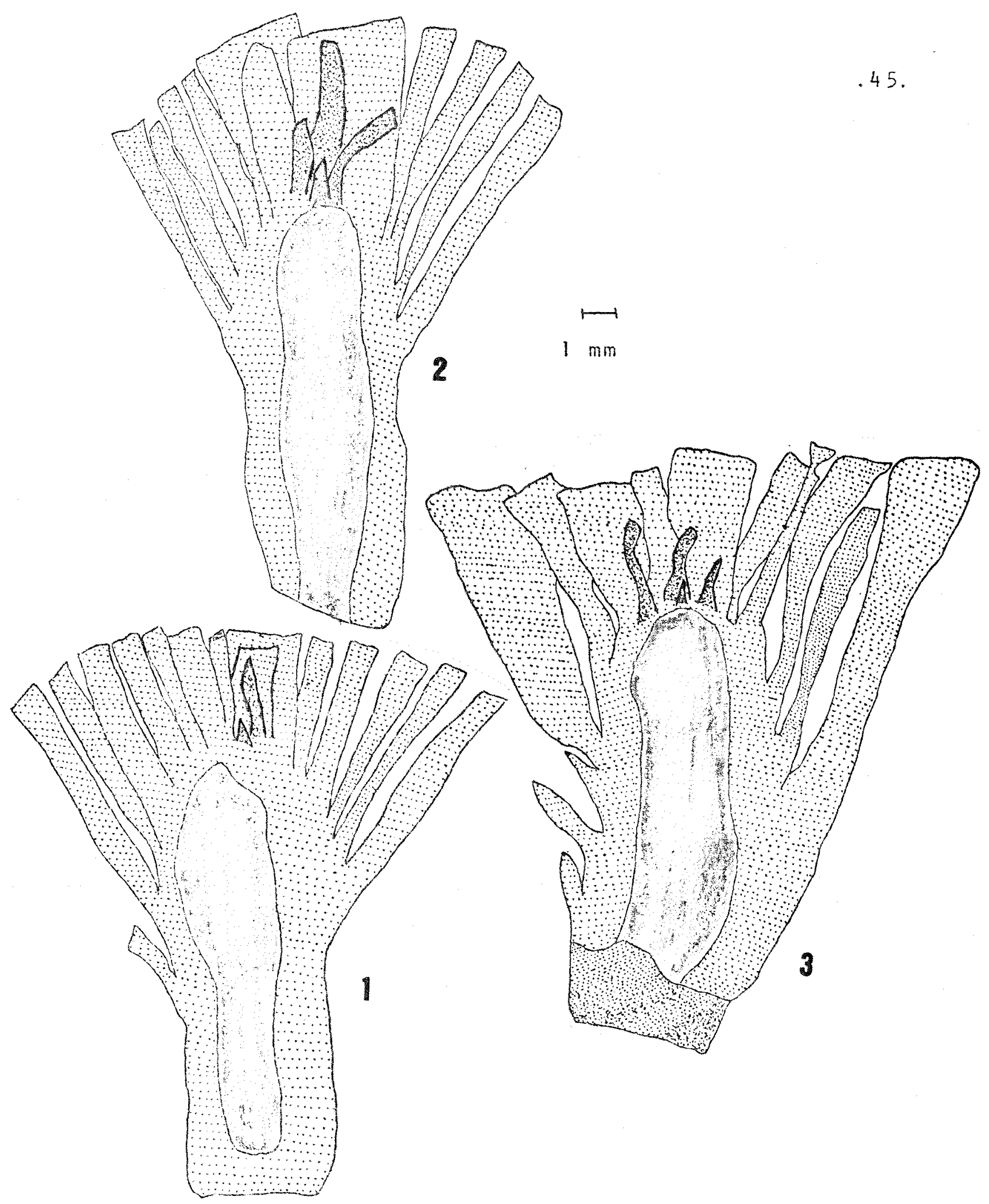

FIGURA 9.A. Cultivares de alface: 1. Brasil 202;2. Brasil 303; 3. Boston Branca. Nümero de folhas por planta aos 56 dias da emergēncia. Esquematizadas em camara clara. 


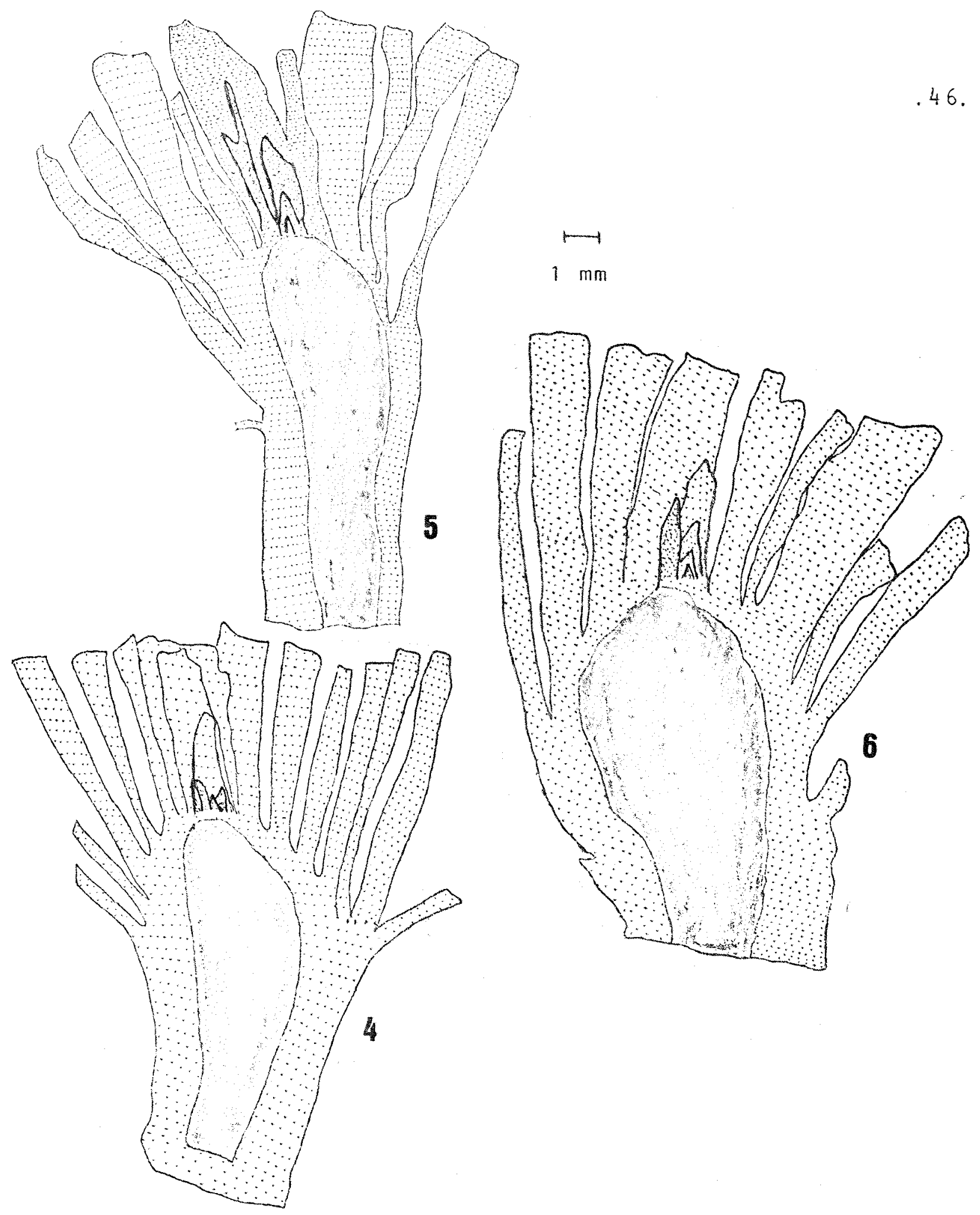

FIGURA 9.B. Cultivares de alface: 4. Grand Rapids; 5. Babä; 6. Grandes Lagos. Número de follhas por planta aos 56 dias da emergência. Esquematizadas em ca mara clara. 
A anälise de variància desta amostragem não acusou diferenças significativas entre os cultivares no que se refere a nümero de folhas emitidas por planta.

Aos 85 dias da emergência foi feita outra amostragem no nümero de folhas em plantas totalmente desenvol vidas e seus resultados podem ser verificado na Tabela 8.

TABELA 8. Médias de número de folhas por planta aos 85 dias da emergência da plântula.

\begin{tabular}{|c|c|c|c|c|c|c|}
\hline \multirow{2}{*}{ Cultivares } & \multicolumn{5}{|c|}{ Repetições } & \multirow{2}{*}{ Médias } \\
\hline & 1 & 2 & 3 & 4 & 5 & \\
\hline 1. Br. 202 & 61,5 & 50,5 & 68,0 & 58,0 & 58,0 & 59,20 a \\
\hline 2. Br. 303 & 50,0 & 60,5 & 49,5 & 54,0 & 53,0 & 53,40 ab \\
\hline 3. B. Branca & 42,5 & 48,0 & 40,5 & 38,0 & 43,5 & 42,50 a \\
\hline 4. G. Rapids & 45,5 & 46,5 & 52,0 & 49,0 & 48,0 & 48,2 \\
\hline 5. Babà & 46,0 & 54,5 & 48,5 & 52,5 & 53,0 & 50,90 abc \\
\hline 6. G. Lagos & 34,5 & 47,0 & 47,0 & 45,5 & 44,0 & 43,60 \\
\hline
\end{tabular}

$\operatorname{DMS}(5 \%)=8,35$

$C V \%=9,0$

As médias seguidas da mesma letra não diferem entre si pelo teste de Tukey.

Observa-se que houve um grande aumento de nümero de folhas por planta quando comparado com a contagem feita aos 56 dias. Os incrementos variaram de 
.48.

$151 \%$ a $286 \%$ em relação às tomadas na ocasião de 29 dias antes.

As médias no nümero de folhas variaram de 43,6 a 59,2 nos diferentes cultivares Existe uma acele ração de desenvolvimento de nümero de folhas nos interva los de 29 dias que dista entre 56 e 85 dias de idade da planta.

Foi verificado que houve diferença altamente significativa entre os cultivares, equanto ao nümero total de folhas por planta; onde 'Brasil 202', 'Bos ton Branca', não diferiram do 'Brasil $303^{\prime}$, 'Babä' e foram superiores ao'Grand Rapids' e 'G. Lagos'. O 'Brasil $303^{\prime}$ foi tambëm superior ao'Grandes Lagos'; e finalmente a 'Babà' e 'Grand Rapids' não diferiram do 'Grandes La$\operatorname{gos}^{\prime}$

A $\ddot{u}$ t tima amostragem do experimento foi feitaaos 92 dias da emergência, com a contagem do nümero de folhas em plantas totalmente desenvolvidas e cujos da dos podem ser observados na Tabela 9. 
.49.

TABELA 9. Médias de nümero de folhas por planta aos dias da emergência da plàntula.

\begin{tabular}{|c|c|c|c|c|c|c|c|}
\hline \multirow{2}{*}{ Cultivares } & \multicolumn{5}{|c|}{ Repeticões } & \multirow{2}{*}{\multicolumn{2}{|c|}{ Médias }} \\
\hline & 1 & 2 & 3 & 4 & 5 & & \\
\hline 1. Br. 202 & 64,5 & 56,0 & 52,0 & 64,0 & 54,5 & 58,20 & $a$ \\
\hline 2. $\mathrm{Br}, 33$ & 61,0 & 62,5 & 61,0 & 58,5 & 59,0 & 60,40 & $a$ \\
\hline 3. B. Branca & 47,0 & 50,0 & 56,5 & 55,5 & 52,5 & 52,30 & $b$ \\
\hline 4. G. Rapids & 58,5 & 49,5 & 51,5 & 56,5 & 55,0 & 54,20 & a \\
\hline 5. Babà & 38,5 & 44,0 & 48,5 & 48,0 & 46,5 & 45,10 & $b c$ \\
\hline 6. G. Lagos & 39,1 & 43,5 & 48,5 & 38,0 & 41,5 & 42,50 & $c$ \\
\hline
\end{tabular}

$\operatorname{DMS}(5 \%)=7,54$

$\mathrm{CV} \%=7,8$

As médias seguidas da mesma letra näo diferem entre si pelo teste de Tukey.

Comparando-se com os dados obtidos aos 85 dias, pode-se verificar que houve aumentos variáveis de número de folhas em sete dias apōs. Nas variações que hou veramentre um mesmo cultivar, deve-se notar que foi possivelmente devido às variações de vigor das plantas que entraram nas duas ültimas contagem realizadas.

Na anälise de variància apresentaram-se finalmente com maiores nümeros de folhas a nivels altamente significativo, os cultivares Brasil 202, Brasil 303, que o 'Grand Rapids' e 'Grandes Lagos'. O 'Brasil 
$303^{\prime}$ nào diferiu do 'Grand Rapids', 'Brasil 202' e 'Boston Branca'; porëm, tambëm foi superior ao'crandes Lagos'. Este apresentou-se no final do ensaio o menor nümero de folhas por planta.

A emissäo do nümero de folhas nas

plantas foi iento no começo do ciclo e se comportou' de uma maneira geral para todos as cultivares estudados no ensaio, como podem ser observados nos histogramas da Figura 10 .

Nas primeiras observações feitas a duas semanas após a emergência as plantas tinham en média de 4,6 a 5,6 folhas; na terceira semana aumentou para 6,1 a 7,6 folthas por planta; na quarta semana atingiu uma mëdia de 7,5 a 8,5 folhas por planta; na sexta semana a 11.5 a 13.9 ; e na sétima a tingiu uma média variävel de 14,0 a 16,8 folhas por planta para os diferentes cultiva ís. Tendo-se assim, uma produçäo média de 2,3 folhas por semana a partir da emergência até 56 dias, durante 5 semanas consecutivas. Nas contagens realizadas aos 85 dias a emergência foi verificado que nesse intervalo de 29 dias de uma amostragem a outra, houve um grande aumen to de produçáo de folhas. Da média de 17 folhas por planta que tentra os cultivares aos 56 dias da emergência, incrementouse a uma média que variaram de 43,6 a 59,2 


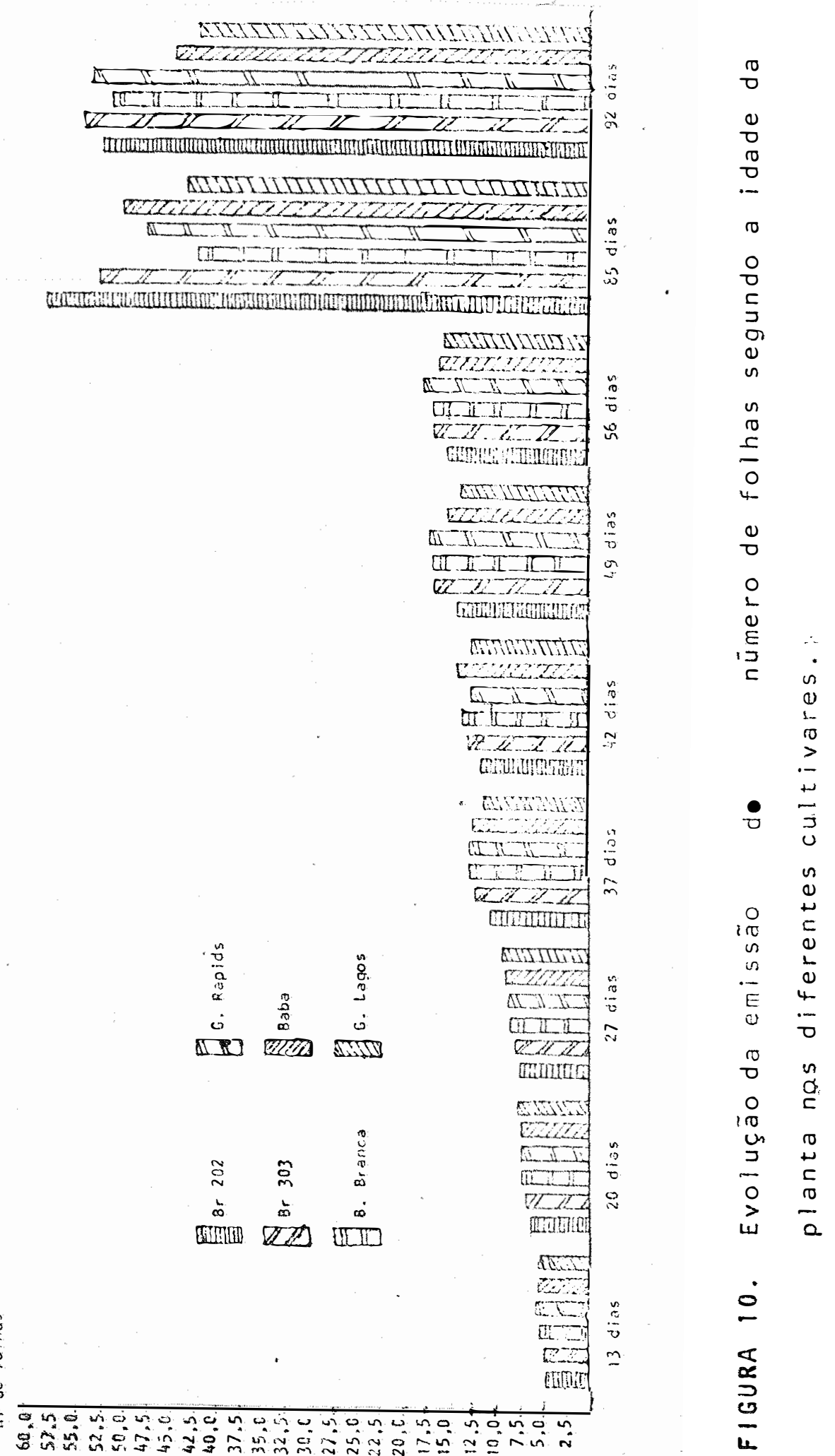


folhas por planta nos diferentes cultivares; dando-se um aument semanal variàvel de 7 a 11 folhas por semana nas 4 semanas consecutivas, para os diferentes cultivares. Na Figura 11 observa-se o nümero total de folhas de uma planta do cultivar Grand Rapids com 85 dias de idade.

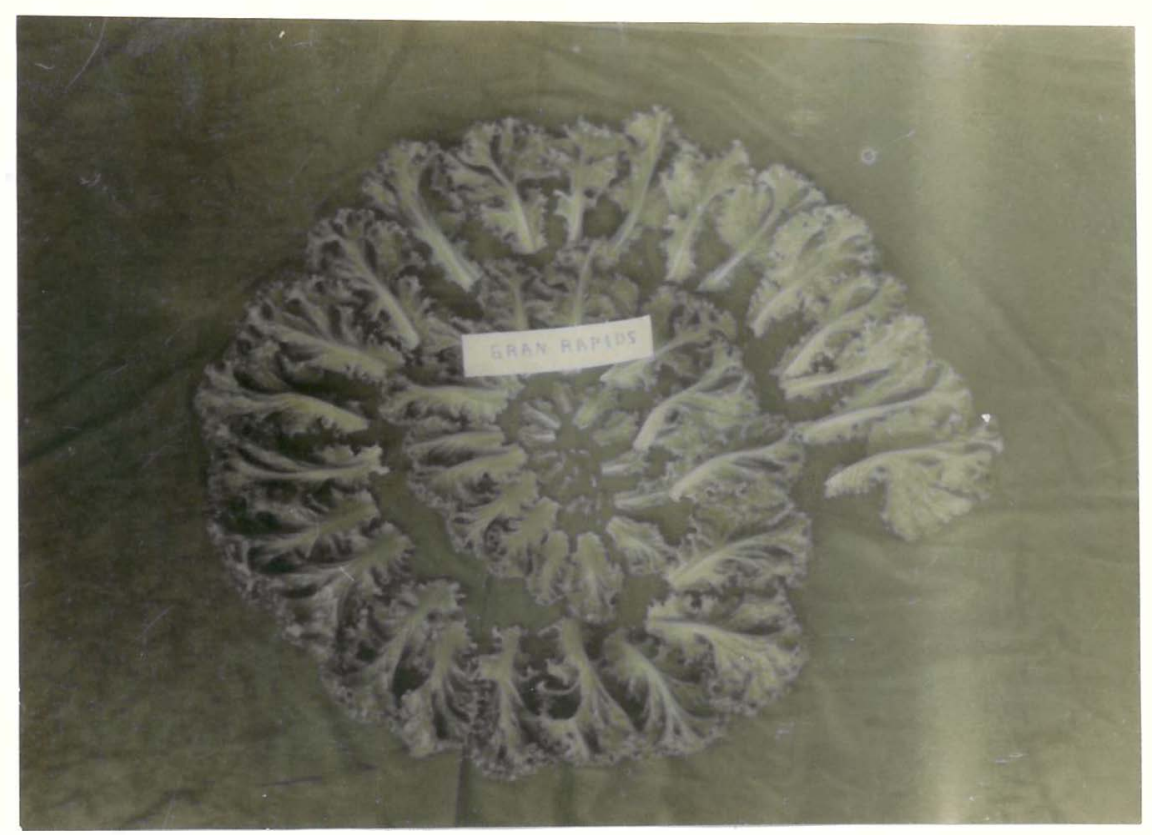

FIGURA 11. Nümero total de folhas de uma planta do culti var Grand Rapids com 85 dias da emergēncia.

$\mathrm{Na}$ ültima contagem aos 92 dias da emergên cia apresentou médias de 42,5 a 60,4 folhas por planta, não havendo novos aumentos em comparação aos dados obtidos aos 85 dias.

Os resultados deste ensaio são bastante 
aproximados aos poucos trabalhos que existem na literatu ra sobre o assunto.

NOTHMANN (1976) encontrou na alface do ti po romana ou cos que o desenvolvimento de nümero de folhas foi relativamente lento no começo du ciclo. A partir de 21 dias da emergência a taxa de produção média de 3 folhas por semana durante 5 semanas concecutivas, até 56 dias, onde atingiu uma média de 17 folhas por planta; mais tarde, com o início de formação de cabeça, a taxa aumentou rapidamente com uma média de 10 folhas por sema na. Assim aos u3 dias rinha uma média de 26 folhas por planta; aos 69 dias, 32 folhas; aos 76 dias, com 42 foIhas; aos 83 dias, com 51 folhas; 90 dias, com 61 folhas; e aos 96 dias, na média de 71 folhas por planta on de houve início do pendoamerto e final do ciclo de desen volvimento vegetativo.

Bensink, citado por RYDER (1979) encontrou também que a planta de alface produz folhas essencialmente na forma linear com a idade. O indice de número de folhas tambëm aumenta com o aumento da intensidade de luz e temperatura constante, ou com incremento de temperatura e luz constante. Afirmou também que tanto o desenvolvimento como o crescimento dependeudas condiçães ambientais. 


\section{CONCLUSÕES}

Os resultados do experimento para as condições estudadas permitiram as seguintes conclusões:

1. A taxa de emissão de folhas nos diferentes cultivares, desde a emergência da plântula até 56 dias, foi em for ma gradativa e lenta com uma mëdia de 17 folhas por planta, e uma média de 2,3 folhas por semana. Nas qua tro semanas seguintes até 85 dias a taxa de emissão a $\underline{u}$ mentou grandemente com médias variäveis de 42,5 a 59,2 folhas por planta, o que dä uma mëdia de 7 a 11 folhas por semana; o que indica que houve aumentos na taxa de emissäo de folhas de $15 i$ a $286 \%$, conforme o cultivar. Na ültima contagem, feita nos 92 dias da emergência das plàntulas mostrou que o nümero de folhas variaram em mëdia de 42,5 a 60,4 nos diferentes cultivares. 
.55 .

2. O método de câmara clara utilizado para acompanhar a emissão e crescimento das folhas, e desenhar os diferentes estägios foliares da alface foi útil e eficiente.

3. O método de fixador Nawaschin utilizado para conservaf̧ão das amostras de plantas tomadas semanalmente foi eficiente e útil para conservar o material vegetal por muito tempo em boas condições de ser trabalhada. 


\section{Literatura Citada}

BERNARDI, J.B. e T. IGUE, 1967. Comportamento de variedades de alface na região de Bampinas. Bragantia. Campinas $26(4): 239-234$.

BERNARDI, J.B. e T. IGUE, 1969. Comportamento de variedades de alfave na região de Campinas. Parte 11. Bragantia. Campinas, 26(11): 148-154.

BERNARDI, J.B. e T. IGUA, 1973. Comportamento de cultivares de alface na região de Campinas, de setembro a novembro de 1972. Revista de OLericultura. Brasilia, 13: 29-31.

BERNARDI, J.B. MARTINS e T. IGUA, 1973. Comportamento de cul tivares de alface (Lactuca sativa L.), na região de Jundiai, cultura de junho a agosto de 1973. Revista de olericultura. Santa Maria, 14:40-41.

BERNARDI, J.B.; R.S. LISBAO e T. IGUE, 1975. Comportamento de cultivares de alface na região de Campinas, Cultura de março a maio de 1974. In: CONGRESSO DA SOCIEDADE BRASILEIRA DE OLERICULTURA. Botucatu. 
BUKOVAG, M.J. e S.H. WITTWER, 1958. Reproductive responses of lettuce (Lactuca sativa var. Greak Lakes) to gibberellin as influenced by seed, vernalization, photoperiod and temperature. Proo. Am. Soc. Hortic. Set. New York, 71 : $707-411$

CAMARGO, J.R.S., 1964. Ensaios de variedades de alface de ve rão. Revista de olericultura. Pelotas 4: 111-115.

CASSERES, E., 1966. Produciön de Hortalizas. Lima, Perü. Instituto Interamericano de Ciências Agricolas de la O.E.A. $354 p$

COUTo, $\vec{F} \cdot A \cdot A ., 1960$. Efeito da temperatura e fotoperiodo em alface: In: Hortalicas, FaseX. Cultura da alface. ETA, Projete 55, UREMIG, Viçosa.

EDMOND, J.B.; T.L. SENH E F.S. ANDREWS, 1867. Principios de Horticuttura, Cominental S.A., Mëxico, 575 p.

FELIPE, M.G., 1979. Desenvolvimento. In: Fisiologia Vegetal, v. 2. Marto Guthes Ferri, Coord. São Paulo, EPU/ EDUSP, p. $1-37$.

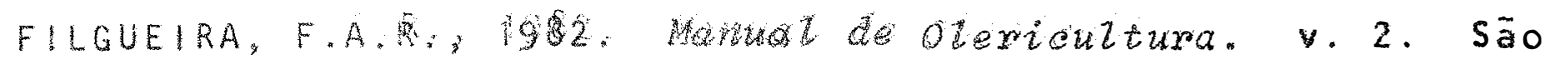
Paulo. Editera Agronomica Ceres. 336 . 
HARRINGTON, J.F. E Z.C. THOMPSON, 1952. Effect of variety and area of production on subsequent germination of lettuce seed at high temperature. Proc. Am. Soc. for Hortic. Sei. New York. 59: 445-450.

KAHN, A., 1960. Promotion of lettuce seed germination by giberellin. Plant Physiology. Massachusetts 35: 333-339.

KNOTT, J.E., 1956. Hanabook for vegetable growers. New York, Jonn wiley. $238 \mathrm{p}$.

NOTHMANN, J., 1976a. Morphology of head formation of cos lettuce (Lactuca sativa L. CV. Romana). 1. The Process of Hearting - Annals of Botany. Oxford, 40: 1067-1072.

NOTHMANN, J., 1976b. Morphology of head formation of cos lettuce (Lactuca sativa L. CV. Romana). 2. The development of spiral-leaved heads. Annals of Botany. $0 \times f$ ord, $40: 1073-1077$.

NOTHMANN, J., 1977a. Effects of soil temperature on head development of cos lettuce. Scientia Horticulturae. Netherlands, I: 77-105.

NOTHMANN, J., 1977b. Morphogenetic effects of seasonal conditions on head development of cos lettuce (Lactuca sativa L. Var. Romana) growing in a subtropical climate. Seientia Hopticultural Netherlands, 12: 155-162. 
PEREIRA, A.L. e L.B. BATISTA, 1975. Competição de cultivares de alface (Lactuca sativa L.) na Baixada Carioca-Fluminense. Revista de Ozericultura. Botucatu, 15: 125-126.

PEREIRA, A.L. e L.B. BATISTA, 1976. Competição de cultivares de alface (Lactuca sativa L.) na Baixada-Fluminence. Revista de olericultura. Lavras, 16: 25 .

PEREIRA, A.L.; C.C. NOVIS; K.L. SARDOV, 1980. Avaliação de cultivares de alface na Baixada Fluminense. In: XX CONGRESSO BRASILEIRO DE OLERICULTURA, Brasilia, Resumos, EMBRAPA. P. 41.

RAPPAPORT, L. e S. WITTWER, 1952. Flowering in head lettuce as influenced by seed vernalization, temperature and photoperiod. Proc. Am. Soc. Hort. Sci., New York. 59: $372-376$

REGHIN, M.Y. e T.A. LOIOLA, 1982. Comparação de cultivares de alface na época quente em Bandeirantes - PR. Poliagro, Bandeirantes. $\quad 4(1-2): 67-79$.

RYDER, E.J., 1979. Leafy Salad Vegetables, Connecticut, AVI, $266 \mathrm{p}$.

SASS, J.E., 1958. Botanical Microtechique. 33. ed. lowa State University. Iowa. $228 \mathrm{p}$. 
SENO, S.; T. KIMOTO e M.M. MISCHAN, 1980. Comportamento de cultivares de alface semeadas em diferentes ëpocas do ano, na região de llha Solteira, SP. In: CONGRESSO BRASILEIRO DE OLERICULTURA. 20. Brasilia. EMBRAPA, p. 43-44.

SONNEMBERG, P.E., 1971. Competição entre sete variedades de de alface na ëpoca quente em Goiania. In: XI Reunião da Sociedade Brasileira de Dlericultura.

SCAIFE, M.A., 1973. The early relative growth rates of six lettuce cultivars as affected by temperature. Annals of Applied Biology. New York. I4: 119-128.

TIBBIS, T.W. e G.E. BOTTENBERG, 1976. Growth of lettuce under controlled humidity levels. J. Am. Hortic. Sci. $101(1): 70-73$

THOMPSON, H.C. e J.E. KNOTT., 1933. The effect of temperature and photoperiod on the Growth of lettuce. Proc. Am. Soc. for Horticultural Science. New York, 30: 507-509.

VIGGIANO, J. e R.S.L. MEDINA; 1980. Competição de cultivares de alface (Lactuca sativa L.) do grupo repulhuda com foIhas Iisas. In: XX CONGRESSO BRASILEIRA DE OLERICULTURA. Resumos, EMBRAPA, p. 42. 
.61.

YOKOYANA, S.; A.C.P. SILVA; J.J.U. MULLER, 1979. Comportamen to de cultivares de alface (Lactuca sativa L.) durante o verão no baixo vale de Itajai, In: XIX CONGRESSO BRASILEI RO DE OLERICULTURA. Florianöpolis, EMPASC. p. 5-7.

ZINK, F.W., 1959. Development of spiraled heads in Greak Lakes lettuce. Proc. Am. Soc. for Hortic. Sci., New York. 73: $377-385$. 